\title{
4. SITE 373: TYRRHENIAN BASIN
}

\author{
Shipboard Scientific Party ${ }^{1}$
}

\section{SITE DATA}

Position: $39^{\circ} 43.68 \mathrm{~N}, 12^{\circ} 59.56 \mathrm{E}$

Water Depth (sea level): 3517 corrected meters, echo sounding.

Bottom Felt at: 3507 meters, drill pipe.

Penetration: 457.5 meters.

Number of Holes: 1

Number of Cores: 12

Total Core Recovered: 27.5 meters

Percentage Core Recovery: $24.1 \%$

Oldest Sediment Cored:

Depth subbottom: 270 meters

Nature: Marl

Age: Early Pliocene

Basement:

Depth subbottom: $270-457$ meters

Nature: Basalt breccias, and flows.

Principal Results: Site 373 was located on the flank of a seamount in the central Tyrrhenian Abyssal Plain (Figure 1 ), and its prime objective was to sample the basement. The original hole was positioned too high on the flank and the bottom-hole assembly could not be stabilized. Hole $373 \mathrm{~A}$ was an 800 -meter offset to the west, where acoustic basement was encountered at 270 meters, and the hole was terminated in basalt at 457.5 meters. A PlioQuaternary sequence of nannofossil marls, zeolite marls, and volcanic ashes and sands overlies a basaltic basement complex of calcareously cemented basalt breccias and flow basalts. The limestone matrix of the basaltic breccias contained foraminifers dated as not older than middle Miocene and is probably early Miocene. The flow basalts were extensively altered despite a penetration almost 200 meters beyond the top of basement. This basement complex bears a general resemblance to that encountered

${ }^{1}$ Kenneth J. Hsü (Có-chief scientist), Eidg. Technisches Hochschule, Geologisches Institut, Zurich, Switzerland; Lucien Montadert (Co-chief scientist), Division Geologie, Institut Francais du Petrole, Rueil Malmaison, France; Daniel Bernoulli, Geologisch-palaontologisches Institut der Universitat Basel, Basel, Switzerland; Germaine Bizon, Bureau d'Etudes Industrielles et de Cooperation de l'Institut Francais du Petrole, Rueil Malmaison, France; Maria Cita, Instituto di Geologia, Universita degli Studi di Milano, Milano, Italy; Al Erickson, Department of Geology, University of Georgia, Athens, Georgia; Frank Fabricius. Institut fur Geologie Techn. Universitat, Munich, Germany; Robert E. Garrison, University of California, Santa Cruz, California; Robert B. Kidd, Institute of Oceanographic Sciences, Wormley, United Kingdom; Frederic Mélières, Laboratoire de Geologie Dynamique, University of Paris, Paris, France; Carla Müller, Geologisch-Paleontologisches Instutut der Johann Wolfgang Geothe-Universitat, Frankfurt, Germany (Present address: Bureau d'Etudes Industrielles et de Cooperation de L'Institut Francais du Petrole, Rueil Malmaison, France); Ramil C. Wright, Beloit College, Department of Geology, Beloit, Wisconsin (Present address: Department of Geology, The Florida State University, Tallahassee, Florida. in drilling on the Mid-Atlantic Ridge. Basalt volcanism undoubtedly played a role in the genesis of the Tyrrhenian Basin.

\section{BACKGROUND AND OBJECTIVES}

\section{Background}

The understanding of the origin and evolution of the so-called small ocean basins and marginal seas is of critical importance in furthering our knowledge of ocean-continent relationships (Figure 2). Various hypotheses have been put forward as to the origin of the Tyrrhenian Sea. Among them are: (a) the Tyrrhenian Basin is a relic of a once wider oceanic basin, perhaps as old as the Permian (Glangeaud, 1962); (b) the Tyrrhenian Basin is a marginal back-arc basin created as a consequence of lithospheric subduction at a plate margin beneath the Ionian Basin; and (c) the Tyrrhenian Basin was created in the late Tertiary by rapid subsidence of a continental craton. Recovery of basement samples beneath the Tyrrhenian Abyssal Plain is an essential first step in solving the problem. If the southern Tyrrhenian Sea is a relic of an ancient ocean basin, it should be underlain by typical oceanic "layer 2 " type material (abyssal tholeiitic basalt) of rather old age and be characterized by low heat-flow values typical of old ocean basins. If it is a recently formed, back-arc marginal basin, young oceanic-type crust should underlie it. If, on the other hand, granite or metamorphic rocks were sampled at depth within the central abyssal plain province, then it would provide a strong confirmation of the hypothesis of oceanic subsidence of cratonic basement. However, the Tyrrhenian Abyssal Plain is commonly underlain by a sedimentary sequence including evaporite deposits. Except locally on basement ridges, a relatively deep penetration through evaporites is required before the basement can be sampled.

Two types of basement highs have been recognized by geophysical surveys. On the edge of the Tyrrhenian Abyssal Plain are a number of "highs" not associated with magnetic anomalies. Drilling elsewhere in the western Mediterranean during Leg 13 has shown that this type of "basement high" represents subsided sialic crust bounding the central abyssal proyinces (e.g., Sites $121,134)$. A second type of "basement high," most typical of the central abyssal provinces, is characterized by highly positive magnetic anomalies. These are most probably seamounts or submarine volcanoes. Dredging on the Tyrrhenian basement highs has proven the existence of both types of basement. 

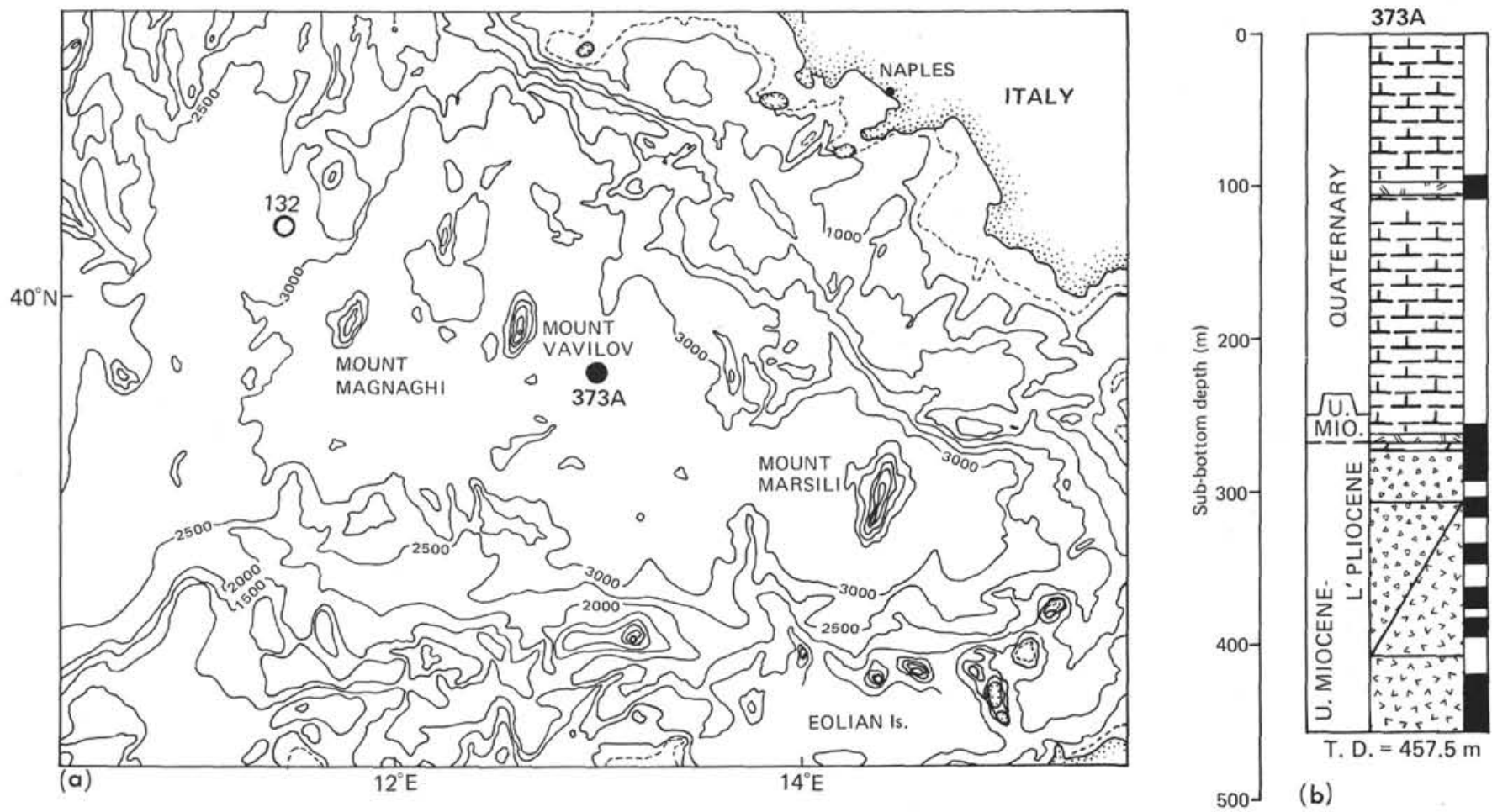

Figure 1. (a) Site location map (depth contours in meters); and (b) generalized hole summary.

\section{Objectives}

There was considerable discussion during the meetings of the Mediterranean Advisory Panel concerning the priority of drilling in the Tyrrhenian. Selli and associates presented arguments in favor of drilling on a nonmagnetic basement high (Site M-6 Alternate, $39^{\circ} 23 \mathrm{~N}, 11^{\circ} 42 \mathrm{E}$ ). Gasparini, Cita, Ryan, and Bonatti, on the other hand, argued strongly for drilling on a Tyrrhenian seamount (Site M-6, $39^{\circ} 44 \mathrm{~N}, 13^{\circ} 00 \mathrm{E}$ ). It seemed a foregone conclusion that we would encounter sialic basement if we drilled on marginal nonmagnetic highs, and that we would encounter volcanic basement if we drilled on seamounts in the central abyssal plain province. The Mediterranean Panel finally decided to give first priority to the proposed M-6 drillsite over the M-6 alternate drillsite on the basis that a sialic basement sample from a marginal basement ridge would not provide more information than that a basin-margin can subside (a foregone conclusion), but that good, fresh basalt samples from a seamount might yield important clues on basin genesis. Since such fresh samples cannot be obtained by dredging, drilling is the only applicable method. The primary objective of Site 373 was, therefore, not so much to prove that basalt underlies this seamount, but to obtain fresh basalt samples for petrological and geochemical studies, which might lead indirectly to an interpretation of the basin genesis.

\section{OPERATIONS}

\section{Site Approach}

On the 27 April Glomar Challenger approached the proposed site from the west southwest. At 0436 LCT the course was changed to $115^{\circ}$ to follow the OGS profile MS-1 (Figures 3 and 4). The basins and seamounts on the reference line were easily recognized. At 0546 LCT the vessel modified its course to $100^{\circ}$. The selected target on the flank of a seamount was reached at 0610 LCT and a $16-\mathrm{kHz}$ beacon was dropped. The crew began to assemble the drill string immediately, and the string reached the sea bed at 1400 LCT, 27 April. It was very difficult to determine precisely the depth of the bottom from the PDR because of the numerous side echoes from the flanks of the seamount. The bottom was encountered by the drill string at 3461 meters some 30 meters above that estimated on the basis of the PDR record.

Only a few meters were penetrated in Hole 373 $\left(39^{\circ} 43.86 \mathrm{~N}, 13^{\circ} 00.10 \mathrm{E}\right)$. The thickness of sediments was insufficient to bury the bottom-hole assembly. It was decided immediately to pull out and to make an 800 -meter offset towards the west where sediments were expected to be thicker. The ship was positioned over Hole $373 \mathrm{~A}\left(39^{\circ} 43.68 \mathrm{~N}, 12^{\circ} 59.56 \mathrm{E}\right)$ by a sideways movement using the thrusters.

\section{Drilling Program}

At 1530 LCT, 27 April, the crew began to lower the drill string to drill Hole 373A. The sea bed was encountered at 1607 LCT, 3507 meters below the rig floor (as opposed to $3517 \mathrm{~m}$ indicated by the PDR record). Drilling operations were begun by washing down 96.5 meters. Core 1 was taken when the core barrel was raised for the first heat-flow measurement at 106 meters subbottom. (Details of all heat-flow measurements and results appear in Erickson and von Herzen, this volume.) After washing down another 19 meters, the second heat-flow measurement was success- 


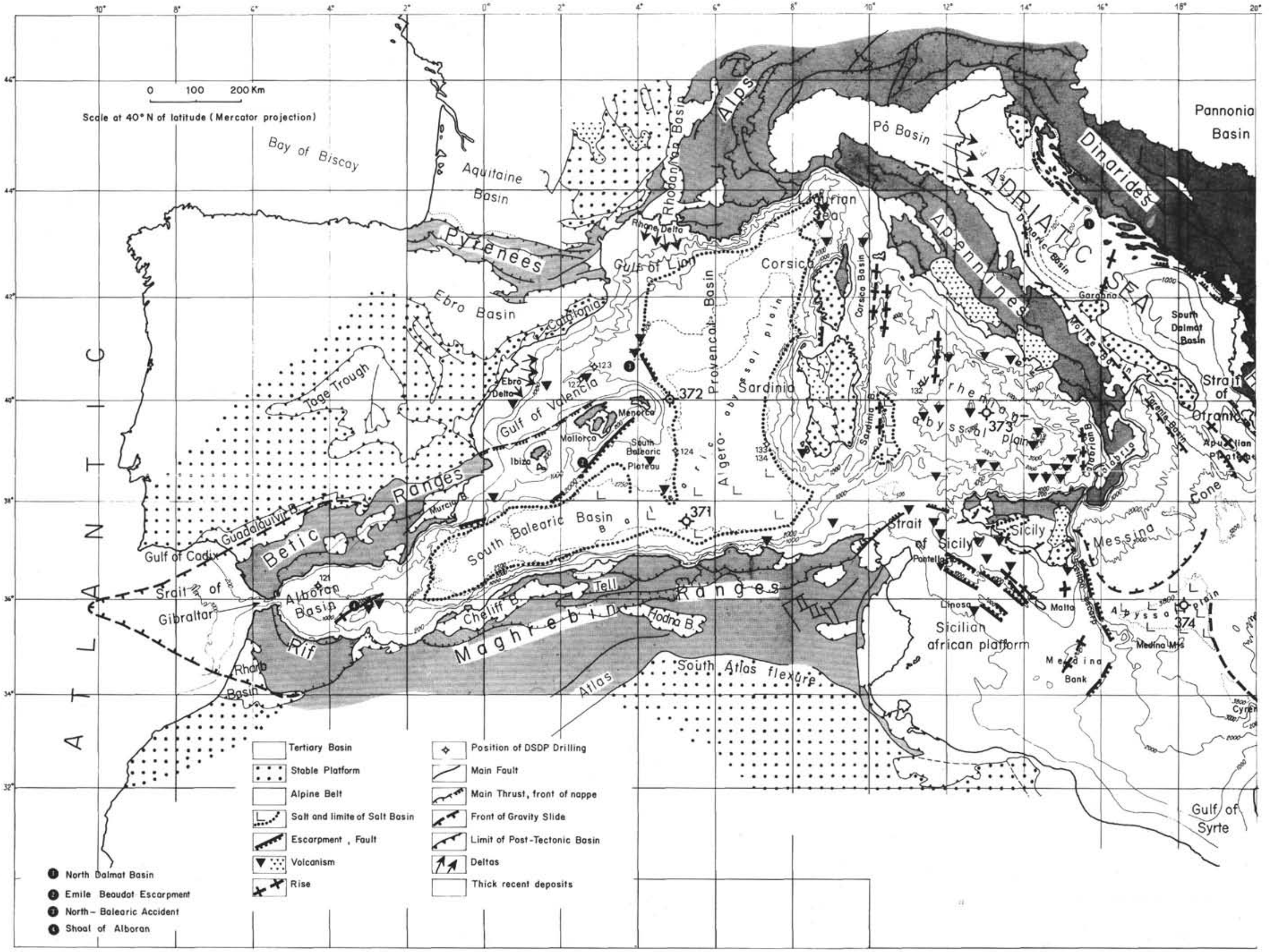

Figure 2. Structural sketch map of the western Mediterranean from Biju-Duval et al. (1974). 


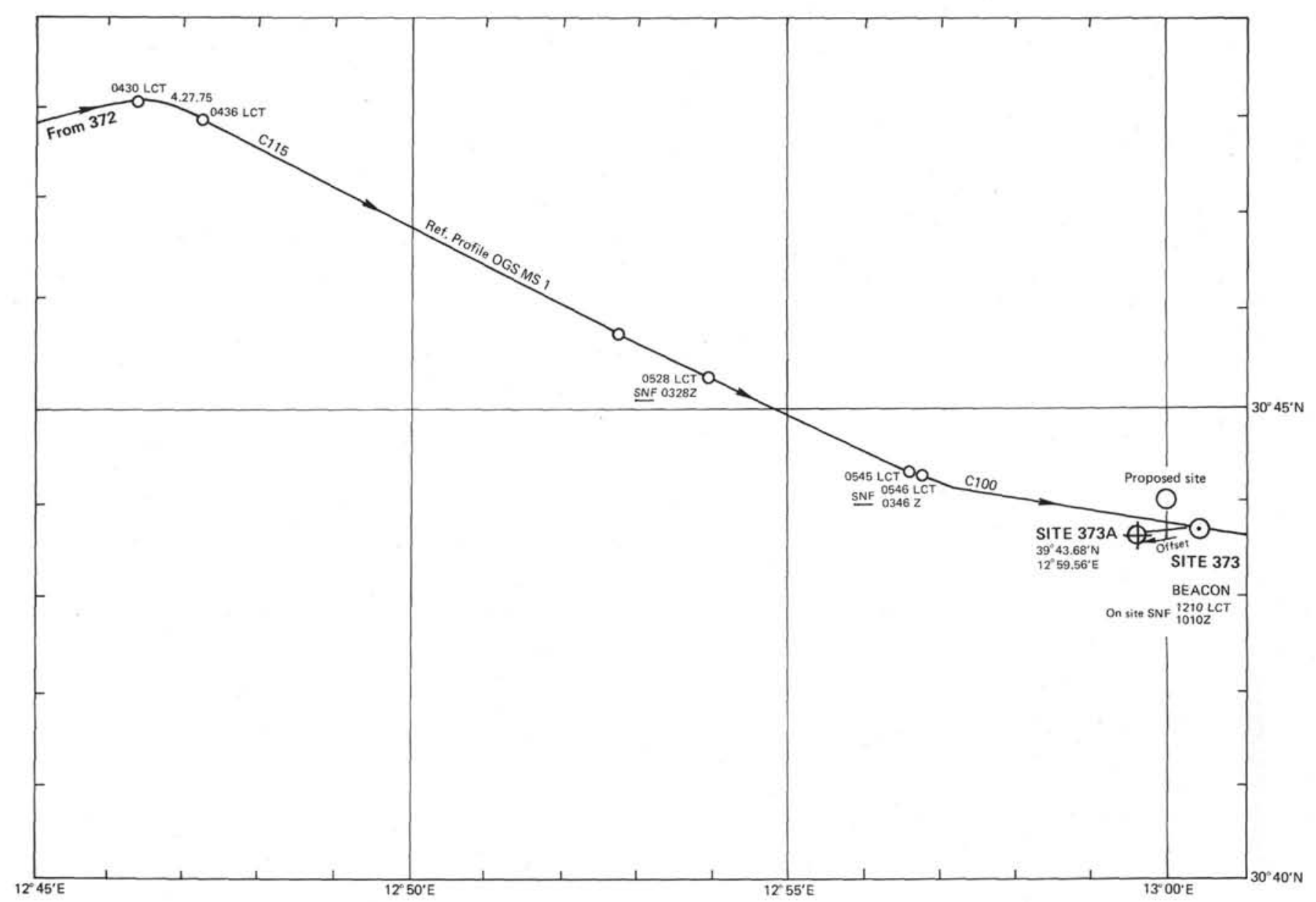

Figure 3. Site approach, Site 373.

fully run at 125 meters. As the reflector was estimated to be within the range 190 to 400 meters subbottom, it was decided to drill ahead. At 2245 LCT and after 267.5 meters of penetration, the reflector had still not been reached. It was decided to core and to raise the barrel for a further heat-flow measurement. It was during this core operation that harder rocks were encountered at 270 meters subbottom. While we were disappointed that another heat-flow measurement could not be made, we were lucky to have sampled, in Core 2 , the contact between the sediment and the volcanic rocks of the acoustic basement.

Cores 3 and 4 were taken successively with about $40 \%$ recovery in basaltic breccias. Since the drilling rate was rapid through the weathered materials, and the thickness of breccia could be considerable, it was decided to drill with intermittent coring so as to reach fresh and unweathered basalt at depth. A basalt layer was encountered in Core 6 and a good recovery of basalt was obtained in Core 7. However, recovery percentages of the later cores were very low because of the need to penetrate an interbedded sequence of hard and soft layers. Various combinations of coring schedules were tried without success. Finally an empty barrel was found when Core 9 was raised 1610 LCT, 28 April.

The empty barrel presented the possibility that it might not be seated properly. The seating seemed correct as the next barrel was pumped into place. At 1810 LCT Core 10 was raised and was found to contain several pieces of fresh basalt. The driller, meanwhile, reported a slow rate of penetration, suggesting that we finally had gone beyond the zone of intense alteration. A continuous coring schedule was begun. At 1830 LCT 75 barrels of mud were pumped down to clean up the hole. Core 11 was recovered at 2130 LCT and was found to contain only pieces of hard basalt. It seemed that a piece of basalt was lodged between the core catchers and had prevented full recovery. At 0100, 29 April, Core 12 was recovered and again was found to consist of a few pieces of hard basalt only. The core barrel had failed to seat. It became apparent that the bottom hole assembly had been plugged by sand and basalt cuttings. Further coring was impossible, and at 0135 the order was given to pull out of the hole (see Table 1).

The core barrel was brought on deck at 0900 LCT, 29 April and it was found to contain sand. It was labeled Core 13. The sand included Quaternary and Pliocene fossils and was obviously a downhole slump debris. The drill collar was brought on deck $10 \mathrm{~min}$ later. The collar and the bit were found to have been plugged by several large pieces of basalt and a large amount of basalt cuttings. The cuttings were transferred into two sections of plastic liner and labeled as $\mathrm{OB}$ (outer bit) samples while the basalt fragments were 


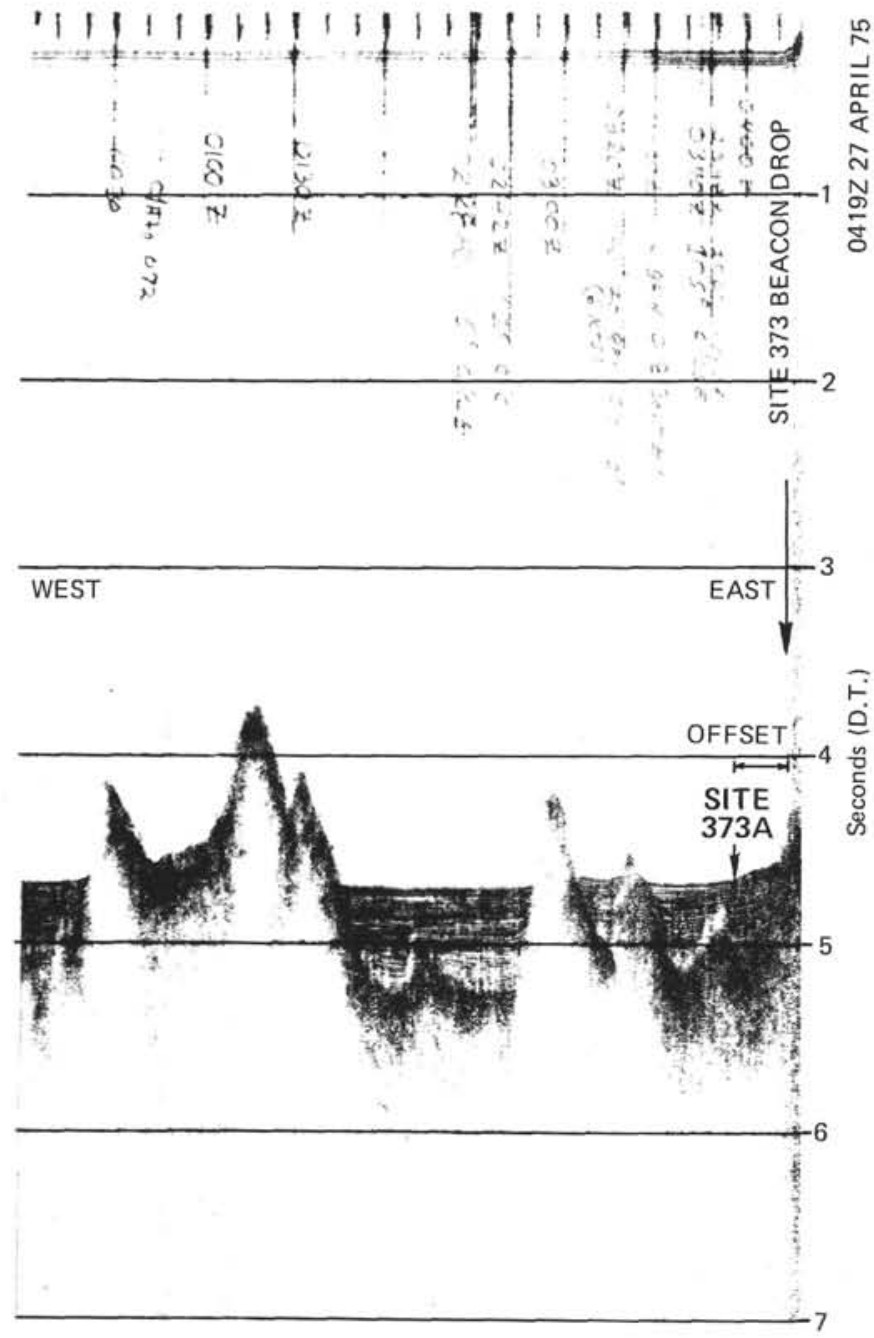

Figure 4. Glomar Challenger seismic profile of approach to Site 373.

stored in freezer boxes. After the gear was secured, the vessel departed on 0930 LCT for Site 374 in the Ionian Basin.

\section{LITHOLOGY}

Sediment and rock recovered from Hole 373A can be divided into five lithologic units (Table 2). Units I and II comprise unlithified sediments which lie above the basaltic basement complex. Units III, IV, and V are subdivisions of this complex.

\section{Unit I}

The dominant lithology of Unit I is nannofossil marl, varying in color from grayish-orange to yellowish-gray to greenish-gray and pale yellowish-brown. Most of the sediment recovered in Core 1 was very soft and intensely disturbed by the drilling. Major constituents of the marl are clay minerals and nannofossils which typically form $60 \%-80 \%$ of the sediment; the remainder is composed of variable amounts of foraminiferal tests, very fine grained zeolites and volcanic glass fragments, and fine quartz and feldspar grains.

Interlayered with the dominant nannofossil marl are the following minor lithologies:

1) Volcanic ash layers (Sections 1, 3, and 4 of Core 1). Both vitric (50\%-70\% glass) and vitric-crystal (20\%-30\% feldspar, 30\%-50\% glass) ashes are present. Thicknesses of the individual layers could not be determined due to drilling disturbances. Most of the ashes are very poorly sorted. Chemical and optical properties of the glass shards indicate a range in composition from calcalkaline rhyodacites to highpotassic trachytes to phonolites.

2) Volcanic sand and mud. Glass-rich, poorly sorted sandy to silty layers of indeterminant thickness occur in Section 4, Core 1.

3) Zeolitic marl. These sediments have $30 \%-40 \%$ zeolites, $30 \%-40 \%$ clay minerals, and $20 \%-30 \%$ nannofossils. They form layers up to $35 \mathrm{~cm}$ thick in Sections 1 and 2 of Core 1 . The fine-grained phillipsite occur as generally subhedral crystals a few microns long; a few crystals are twinned. Also present are variable amounts of fine volcanic glass which commonly is difficult to distinguish from zeolites in smear slides.

TABLE 1

Coring Sunmary, Site 373

\begin{tabular}{|c|c|c|c|c|c|c|c|}
\hline Core & (April 1975) & Time & $\begin{array}{l}\text { Depth from } \\
\text { Drill Floor } \\
\text { (m) }\end{array}$ & $\begin{array}{l}\text { Depth Below } \\
\text { Sea Floor } \\
\text { (m) }\end{array}$ & $\begin{array}{l}\text { Cored } \\
(\mathrm{m})\end{array}$ & $\begin{array}{l}\text { Recovery } \\
\text { (m) }\end{array}$ & $\begin{array}{c}\text { Recovery } \\
\%\end{array}$ \\
\hline 1 & 27 & 1815 & $3603.5-3613.0$ & $96.5-106.0$ & 9.5 & 5.5 & 58 \\
\hline 2 & 28 & 0015 & $3774.5-3784.0$ & $267.5-227.0$ & 9.5 & 1.8 & 19 \\
\hline 3 & 28 & 0200 & $3784.0-3793.5$ & $277.0-286.5$ & 9.5 & 3.8 & 39.5 \\
\hline 4 & 28 & 0345 & $3793.5-3803.0$ & $286.5-296.0$ & 9.5 & 3.7 & 39 \\
\hline 5 & 28 & 0600 & $3812.5-3821.0$ & $305.5-315.0$ & 9.5 & 4.0 & 42 \\
\hline 6 & 28 & 0830 & $3841.0-3850.5$ & $334.0-343.5$ & 9.5 & 1.5 & 16 \\
\hline 7 & 28 & 1100 & $3869.5-3879.0$ & $362.5-372.0$ & 9.5 & 5.4 & 57 \\
\hline 8 & 28 & 1315 & $3888.5-3898.0$ & $381.5-391.0$ & 9.5 & 0.6 & 6 \\
\hline 9 & 28 & 1610 & $3926.5-3936.0$ & $419.5-429.0$ & 9.5 & 0 & 0 \\
\hline 10 & 28 & 1810 & $3936.0-3945.5$ & $429.0-438.5$ & 9.5 & 0.2 & 2 \\
\hline 11 & 28 & 2130 & $3945.5-3955.0$ & $438.5-448.0$ & 9.5 & 0.9 & 9.5 \\
\hline 12 & 29 & 0015 & $3955.0-3964.5$ & $448.0-457.5$ & 9.5 & 0.1 & 1 \\
\hline 13 & 29 & 0900 & $3507.0-3967.5$ & & & & \\
\hline $\mathrm{OB}^{\mathrm{a}}$ & 29 & 0910 & $3507.0-3964.5$ & & & & \\
\hline Total & & & & & 114.0 & 27.5 & 24.1 \\
\hline
\end{tabular}

${ }^{\mathrm{a}} \mathrm{OB}=$ "Outer Bit," cuttings collected in plastic liner after terminating drill site. Interval unknown. 
TABLE 2

Lithologies at Site 373

\begin{tabular}{|c|c|c|c|c|c|}
\hline Unit & Lithology & Cores & $\begin{array}{l}\text { Subbottom } \\
\text { Depth } \\
\text { (m) }\end{array}$ & $\begin{array}{l}\text { Interpreted } \\
\text { Thickness } \\
\text { (m) }\end{array}$ & Age \\
\hline 1 & $\begin{array}{l}\text { Nannofossil marl } \\
\text { with interlayers of } \\
\text { zeolitic marl and } \\
\text { volcanic ash }\end{array}$ & 1 & $0-185$ & 185 & Quaternary \\
\hline II & $\begin{array}{l}\text { Nannofossil marl } \\
\text { with two interlayers } \\
\text { of zeolitic marl, } \\
\text { volcanic ash, and } \\
\text { minor zeolitic fora- } \\
\text { miniferal arenite }\end{array}$ & 2 & $185-268.8$ & 83.8 & $\begin{array}{l}\text { Upper } \\
\text { Pliocene }\end{array}$ \\
\hline $\begin{array}{l}\text { III } \\
\text { (a) }\end{array}$ & Ferruginous dolomite & 2 & $268-8-269.1$ & 0.3 & $\begin{array}{l}\text { Lower } \\
\text { Pliocene? }\end{array}$ \\
\hline (b) & $\begin{array}{l}\text { Basaltic breccia with } \\
\text { limestone matrix }\end{array}$ & $3-4$ & $269.1-300.7$ & 31.6 & \\
\hline IV & $\begin{array}{l}\text { Basalt and basaltic } \\
\text { breccia }\end{array}$ & $5-8$ & $300.7-405.2$ & 104.5 & $\begin{array}{l}\text { Upper } \\
\text { Miocene }\end{array}$ \\
\hline $\mathrm{v}$ & Basalt & $10-13$ & $405.2-457.5$ & 52.3 & $\begin{array}{l}\text { to } \\
\text { lower } \\
\text { Pliocene }\end{array}$ \\
\hline
\end{tabular}

4) Sapropelic marl (the remains of a sapropel) occurs in a highly deformed (by drilling) lump at the top of Section 2, Core 1. It is black and contains abundant fine-grained organic material as well as small amounts of plant spores, clay minerals, nannofossils, foraminiferal tests, volcanic glass fragments, and zeolites.

\section{Unit II}

Unit II, recovered in the upper part of Section 1, Core 2, comprises mainly yellowish to greenish-gray nannofossil and foraminiferal-nannofossil marl with minor amounts of fine quartz and feldspar (6\%-7\%). The sediment is moderately consolidated and much less disturbed by drilling compared to Unit II. Interlayered with the marl are two lithologies:

1) Volcanic ash, black to greenish-gray, in layers which average about $25 \mathrm{~cm}$ thick. Both vitric and vitric-crystal varieties are present, and some of the ash layers are calcareous, with abundant nannofossils as admixtures. Refractive index measurements suggest an intermediate composition for the glass.

2) Zeolitic foraminiferal arenite occurs in one well-laminated layer, $10-15 \mathrm{~cm}$ thick. This layer appears to have been current deposited and somewhat winnowed. It consists mainly of planktonic foraminiferal tests and silt-size quartz and feldspar grains. This friable rock is cemented by fibrous zeolite crystals which also partly replace the micritic infillings of foraminiferal shells.

\section{Unit III}

Unit III is mainly a calcareously cemented basaltic breccia. It occurs in Sections 1 and 2 of Core 2, and in Cores 3 and 4. Minimum thickness is 19 meters. Two subunits are recognized.

The contact between Units II and III occurs near the base of Section 1, Core 2, where soft nannofossil marl of Unit II lies above moderate brown, semilithified, ferruginous dolomite which consistitutes Subunit IIIa.
The contact is very sharp, but may represent a drilling artifact. Subunit IIIa consists of about $30 \mathrm{~cm}$ of the dolomite occurring in separate pieces at the bottom of Section 1 and top of Section 2, Core 2; interspersed with the dolomite pieces are pieces of basaltic breccia. The dolomite is very even-grained and consists of $90 \%$ $95 \%$ euhedral to subhedral dolomite rhombs in the size range 5 to $20 \mu \mathrm{m}$. X-ray diffraction indicates this is calcium-rich dolomite with $56 \mathrm{~mol} \% \mathrm{CaCO}_{3}$ Dolomite composes about $80 \%$ of the rock; clay minerals (mainly smectite about 20\%). Dispersed through the dolomite are silt-size grains of pyroxene and feldspar, and 2-10 $\mu \mathrm{m}$ aggregations of reddish-brown iron oxides. The rock also contains scattered, irregular vugs a few hundred microns across, and poorly preserved foraminiferal molds. The presence of the foraminiferal molds suggests that this rock was originally a pelagic calcareous ooze which was dolomitized, through low-temperature diagenetic alteration on the sea floor. The possibility that this dolomite is Messinian is considered unlikely through radiometric dating of the underlying volcanic breccia.

Subunit III occurs in Cores 3 and 4 and consists of basaltic breccias with a variety of complex relationships. Clast size, insofar as it can be determined in a $6.6 \mathrm{~cm}$ diameter core, ranges from sand to small boulder size. The clasts are generally very angular. Some of the basaltic clasts are dark reddish-brown, but the most common kind of clast is olive-black to light olive-gray, vesicular basalt. Some of these (perhaps $20 \%$ ) have partial rims of dark yellowish-orange palagonitized glass, suggesting they may be broken pillow fragments, perhaps originally derived from a broken pillow breccia (cf. Carlisle, 1963). In many other clasts the edges cut through unpalagonitized matrix and abruptly truncate phenocrysts.

In thin sections, most basaltic clasts show a composition of $70 \%-75 \%$ plagioclase, $25 \%-30 \%$ pyroxene, and about $5 \%$ palagonitized or otherwise altered matrix. The main texture is intersertal, i.e., densely packed crystals with a relatively small amount of altered, interstitial glass. Plagioclase composition, estimated by the Michel-Levy method, is labradorite $\left(\mathrm{An}_{50-55}\right)$. Some specimens have large phenocrysts of calcic plagioclase (up to $\mathrm{An}_{84}$ ) with albite and Carlsbad twinning, and with both progressive and oscillatory zoning.

The interparticle carbonates in this breccia are varied and complex. Two main kinds are present:

1) Clear, coarse calcite, frequently showing radiaxial mosaic texture which suggests it was precipitated into void space as a submarine cement, possibly originally as aragonite (Kendall and Tucker, 1973).

2) Fine-grained, light gray and reddish-brown limestone, in some cases containing admixtures of sand to silt-size basaltic fragments. Examination of several thin sections revealed tests of planktonic foraminifers which indicate a probable early Pliocene age. In some instances, portions of these limestones have been partly zeolitized, and most of the micrite in them appears to have been recrystallized. 
The textural relations between the radiaxial calcite, the interclast limestone and the basaltic clasts reveal a very complicated history for this unit (see similar examples described by Garrison, 1972, 1973; and by von Rad, 1974); also further details are provided in Bernoulli et al. (this volume). Following emplacement of the basaltic clasts, there were several episodes of void-filling carbonate precipitation, cementation, and infiltration of younger carbonate ooze into interclast void space. The latter process has produced flat, geopetal floors in some voids. Some interclast areas remain as empty vugs up to $5 \mathrm{~cm}$ across.

\section{Unit IV}

Unit IV is interlayered basalt and basaltic breccia, with a minimum thickness of 85.5 meters. Most of the unit appears to consist of massive basalt with interlayers of basaltic breccia in Cores 5,6 , the top $30 \mathrm{~cm}$ of Core 7 , and the top $19 \mathrm{~cm}$ of Core 8 .

The basalts are porphyritic and vesicular to amygdular, with large plagioclase phenocrysts embedded in a matrix of smaller crystals of pyroxene and some olivine, plagioclase laths, and altered glass. Palagonite has completely replaced the matrix in Core 5 and fills vesicles in Cores 7 and 8 . The matrix in Core 7 is replaced completely by a fibrous, brown pleochroic mineral, possibly nontronite or chlorophaeite; this mineral also partly replaces some of the pyroxene crystals. Coarse clear calcite crystals fill some veins and vesicles, and partly replace some of the large plagioclase phenocrysts.

Possible inclusions of altered sediment and tuffaceous sediment in basalt were noted in Core 7, and strings of "pipe amygdules" (vesicles) were noted in Section 5 of Core 7.

The interlayered basaltic breccias of Unit IV are nearly identical to those of Unit III, except that the clasts appear more tightly packed and there is less interclast carbonate. Dark reddish-brown basalt clasts are abundant in parts of the breccia (e.g., Section 1, Core 6 ); in thin section, these contain small aggregations of hematite dispersed between plagioclase laths.

Unit IV appears to represent a transition between massive flow basalts below and basaltic breccias above.

\section{Unit V}

Unit $\mathrm{V}$, which appears to be entirely flow basalts, was recovered in relatively small amounts in Cores 10 , 11,12 , and in the core catcher of Core 13. Minimum thickness on the unit is 20 meters. The basalt is generally fine grained and occasionally porphyritic, with plagioclase phenocrysts. Textures range from intersertal to subophitic. Plagioclase $\left(\mathrm{An}_{45}-\mathrm{An}_{50}\right)$ forms $45 \%$ to $60 \%$ of the rock, pyroxene $20 \%$ to $25 \%$, and altered matrix $20 \%$ to $30 \%$. The matrix and some of the pyroxenes are completely replaced by a pale brown, fibrous mineral, possibly nontronite.

\section{GEOCHEMICAL MEASUREMENTS} 373.

There were no chemical measurements made at Site

\section{PHYSICAL PROPERTIES}

A minimal physical properties program was carried out at Site 373 , primarily because only the first core contained sediment even marginally suitable for the physical property measurements routinely made aboard ship. Subsequent cores contained basalt and basaltic debris in varying stages of weathering. Oriented sound velocity measurements were made on some of the larger pieces.

\section{Sediments}

The sediments of Core 1 were soft, watery, and consisted of a highly disturbed mixture of volcanic sand and mud plus normal pelagic sediments in varying ratios. Thermal conductivity measurements (Table 7 of Appendix VI) were made on this sediment to provide values for use in computing heat flow at this site. The thermal conductivity of sediment is known to be strongly influenced by porosity; the higher the porosity (or water content), the lower the thermal conductivity. Thus, the very low mean thermal conductivity calculated for this core $(2.14 \pm 0.10 \mathrm{mcal} / \mathrm{cm} \mathrm{sec}$ ${ }^{\circ} \mathrm{C}, n=3$ ) is not surprising.

\section{Basalts}

Sound velocity measurements were made on two coarse-grained and two fine-grained pieces of basalt from Core 7 ( 362.5 to $372.0 \mathrm{~m}$ subbottom). These data are presented in Table 2 of Appendix VI.

Parallel faces were cut on the ends and along the sides of vertically oriented pieces of basalt chosen for their general homogeneity, at least on a scale of $5 \mathrm{~cm}$ or so. Five measurements were made on each piece of basalt in both the vertical and horizontal directions. The velocities determined on the coarse-grained samples $(5.02$ to $5.15 \mathrm{~km} / \mathrm{sec})$ in both the vertical and horizontal directions are systematically higher by $16 \%$ to $18 \%$ than the velocities determined on the finegrained samples ( 4.11 to $4.44 \mathrm{~km} / \mathrm{sec}$ ). Velocities measured on all four pieces showed no systematic tendency for higher sonic velocities to be measured in either the horizontal or vertical directions.

\section{BIOSTRATIGRAPHY}

\section{Summary}

Only 2 cores of the 13 recovered from Site 373, located on the flank of a seamount, yielded fossiliferous sediments (see Figure 5). Besides these, globigerinids were identified in the cement of the volcanic breccias from Cores 3 and 4 . These indicate an age which must be post middle Miocene and is probably Messinian.

Core 1 ( 96.5 to $106 \mathrm{~m}$ ) belongs to the Quaternary. One sapropel was intercalated in this interval. The upper and lower Pliocene were recorded in Core 2, Section 1 ( 267.7 to $269 \mathrm{~m}$ ) (see Figure 6). Pleistocene nannofossils in Core 2 are interpreted as due to drilling contamination.

Planktonic microfossils are well preserved and common in Core 1 but less abundant in Core 2, Section 1, 


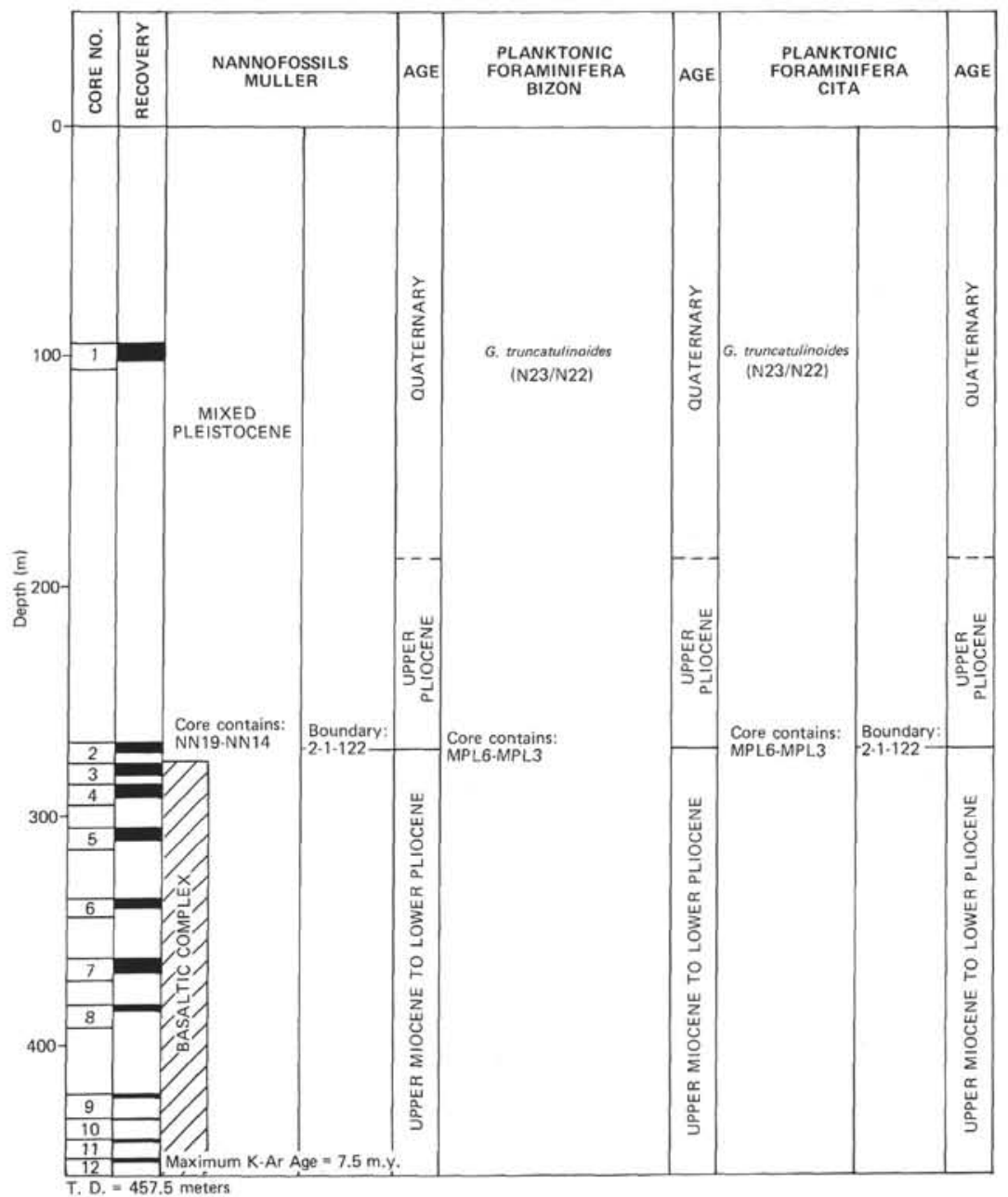

Figure 5. Relative planktonic microfossil determinations, Site 373.

possibly due to the high volcanic ash content of the sediment. A few pteropods, shell fragments, echinoid spines, Radiolaria, ostracodes, and otoliths were recorded in Cores 1 and 2.

\section{Nannofossils}

\section{Quaternary}

Quaternary sediments encountered in Core 1 (96.5$106.0 \mathrm{~m}$ ) contain mixed sediments of the Emiliania huxleyi Zone (NN 21) and the Pseudoemiliania lacunosa Zone (NN 19). Emiliania huxleyi is missing in Section 1 of this core, but it is frequent in Sections 3 and 5. The sediments are rich in well-preserved nannofossils. Coccolithus pelagicus and Umbilicosphaera mirabilis are missing or are rare.

The Pseudoemiliania lacunosa Zone (NN 19) of the lower Pleistocene was determined in Sample 2-1,23-24 $\mathrm{cm}$ with Pseudoemiliania lacunosa, Cyclococcolithus leptoporus, Syracosphaera pulchra, Helicosphaera carteri, and Rhabdosphaera clavigera. This sediment is probably a downhole contamination.

\section{Pliocene}

A Pliocene breccia consisting of a melange of different types of sediments was recovered in Core 2 .
Sample 2-1,53 cm belongs to the Discoaster brouweri Zone (NN 18) with Discoaster brouweri, Coccolithus pelagicus, Helicosphaera carteri, Pseudoemiliania lacunosa, Cyclococcolithus macintyrei, Discolithina sp., Pontosphaera sp., and species of the genus Scyphosphaera. The sample is rich in well-preserved fossils.

Samples 2-1,58 cm, 2-1,70 cm, 2-1,94 cm, 2-1,100 $\mathrm{cm}$, and $2-1,108 \mathrm{~cm}$ are poor in well-preserved nannofossils because of dilution by large amounts of volcanic glass. All of them belong to the Discoaster surculus Zone (NN 16). Sample 2-1,120 cm also belongs to the Discoaster surculus Zone. This sediment is rich in nannoplankton and volcanic glass is absent.

In Sample 2-1,125 cm the Discoaster asymmetricus Zone (NN 14) was determined with Reticulofenestra pseudoumbilica, Coccolithus pelagicus, Cyclococcolithus macintyrei, Sphenolithus abies, Discoaster assymmetricus, Pontosphaera sp., and rare Ceratolithus tricorniculatus.

Sample $2-1,130 \mathrm{~cm}$ is barren of nannofossils; it is rich in idiomorphic dolomite crystals. The sediments included in the volcanic breccia of Cores 3 and 4 are also barren of nannofossils.

\section{Planktonic Foraminifers (Cita)}

Thirteen samples were examined from the unconsolidated sediments of Cores 1 and 2. Additionally fora- 


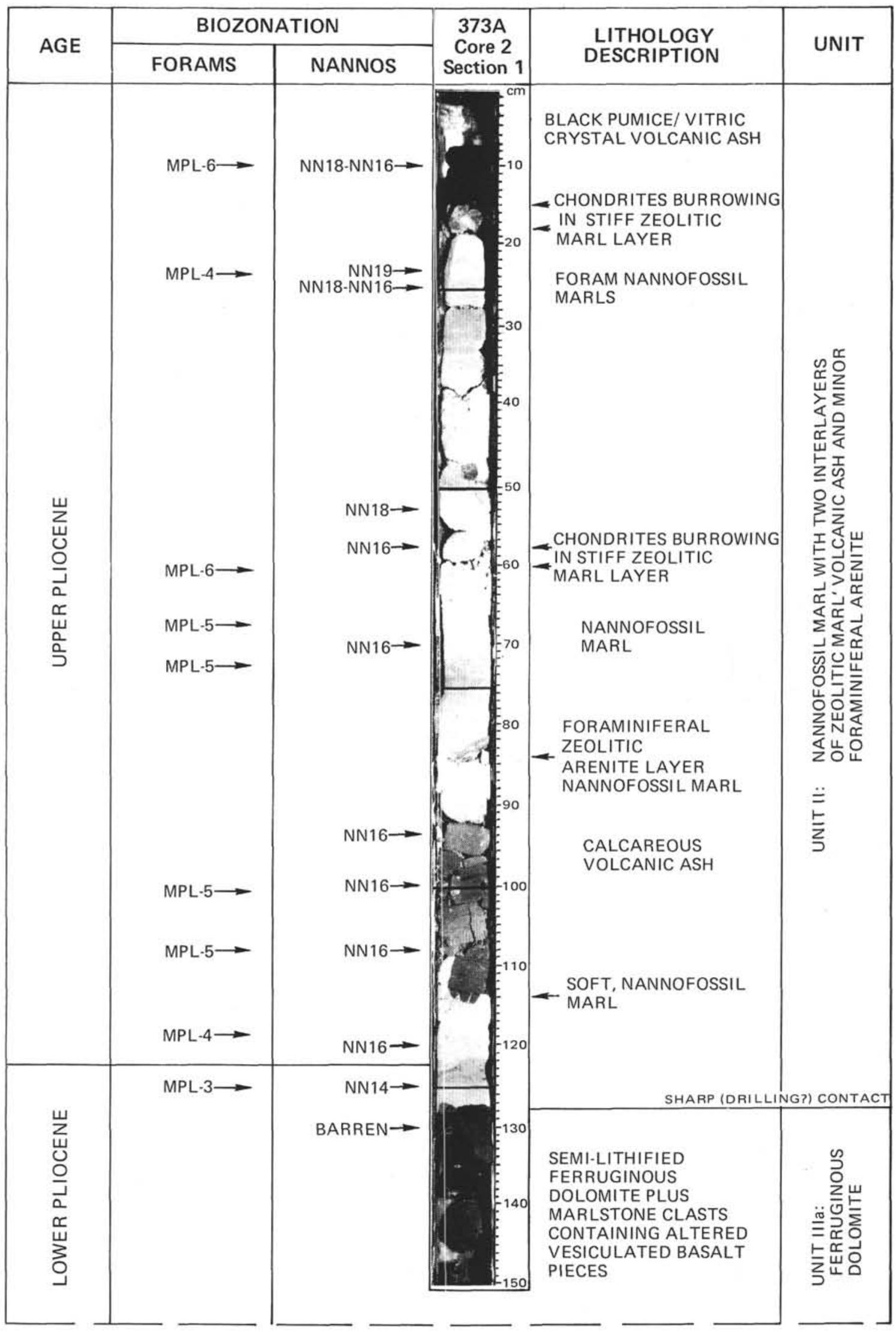

Figure 6. Detailed biozonation of Site 373, Core 2, Section 1. 
minifers were investigated in this section from the cement of the basaltic breccias recovered in Cores 3 and 4.

\section{Pleistocene}

The five samples investigated from Core 1 yielded rich and diversified planktonic assemblages indicating a "glacial" Pleistocene age. By correlation with the nearby DSDP Site 132, which was continuously cored and whose Pleistocene succession has been studied in detail (see Cita et al., 1972), Core 1 can be referred to an interval close to the Brunhes/Matuyama boundary. The core contains: (1) a sapropelic layer in the topmost part of Section 2; (2) several tephra horizons; and (3) the sedimentary expression of at least one major climatic cycle, with a distinct warm peak coincident with the sapropel.

The climatic indications provided by the samples examined are as follows: TC (temperate-cold) for 1-1, $130 \mathrm{~cm}$; WT (warm-temperate) for 1-2, $10 \mathrm{~cm}$; TC for $1-3,78 \mathrm{~cm}$, TW (temperate-warm) for $1-5,122 \mathrm{~cm}$; TC for $1, \mathrm{CC}$.

The foraminiferal species recorded from the sapropelic layer include the warm-water indicators as Globigerina digitata, Globigerinoides sacculifer, G. cf. fistulosus, Hastigerina siphonifera, Orbulina universa, Globigerinoides ruber, and Globorotalia truncatulinoides.

\section{Pliocene}

Core 2 (267.5-277 m subbottom) contains planktonic foraminifers referable to four discrete biozones of the late and early Pliocene within one single section. The faunal assemblages which indicate different ages are from different lumps of sediment, all showing a slightly different lithology (see Figure 6). Two samples from a finely laminated gray sediment recovered at $100 \mathrm{~cm}$ in Section 1 and from a distinctly mottled (burrowed) olive-gray sediment recorded at $108 \mathrm{~cm}$ also from Section 1 were so indurated (diagenized) that they could be processed only after digestion in Varsol over a 3-week period. The fossiliferous intervals identified are as follows:

\section{Late Pliocene}

MP1 6: Two samples, from $10 \mathrm{~cm}$ and $60 \mathrm{~cm}$, respectively, in Section 1, belong to this biozone. Reference is made to the range chart (see Bizon et al., this volume) for a complete list of the taxa identified. They include the zonal marker Globorotalia inflata and also $G$. crassaformis.

MPl 5: Three samples, from $73 \mathrm{~cm}, 100 \mathrm{~cm}$, and $108 \mathrm{~cm}$, respectively, belong to this biozone. The upper two samples yield, among others, the species Globorotalia emiliana and G. puncticulata; the lower one (108 $\mathrm{cm}$ ) yields Globorotalia bononiensis and G. puncticulata. Those from 100 and $108 \mathrm{~cm}$ were lithified.

MPI 4: This biozone, with the zonal marker and Sphaeroidinellopsis seminulina, was identified in a lump of sediment at $119 \mathrm{~cm}$ in Section 1.

\section{Early Pliocene}

MPl 3: The interval corresponding to the concurrent range of Globorotalia margaritae (group) and $G$. puncticulata could be identified in the lowermost fossiliferous sediment overlying the red ferruginous dolomite recorded below $130 \mathrm{~cm}$ in Section 1, and overlying the volcanogenic series. The sample examined was from $125 \mathrm{~cm}$ in Section 1.

\section{Late Neogene}

Fossils identified in thin sections from Samples $373 \mathrm{~A}-3-3,6-11 \mathrm{~cm}, 373 \mathrm{~A}-3-3,129-133 \mathrm{~cm}$, and $373 \mathrm{~A}-$ 4-3, $30-33 \mathrm{~cm}$ include the following taxa: Globigerinoides sp. Early Miocene to Recent; Orbulina universa-middle Miocene to Recent; Globigerinoides ruber-middle Miocene to Recent; Globigerinoides obliquus-early Miocene to early Pliocene; Sphaeroidinellopsis subdehiscens-middle Miocene to late Pliocene.

Some of the taxa are identified with some doubt. The concurrent range of these species indicates an age which cannot be older than the middle Miocene and cannot be younger than the early Pliocene.

\section{Planktonic Foraminifers (Bizon)}

\section{Quaternary}

Core 1 is placed in the Quaternary (Globorotalia truncatulinoides Zone). Samples taken at $1-1,90 \mathrm{~cm}$, $1-2,72 \mathrm{~cm}$, and $1-3,46 \mathrm{~cm}$ yielded planktonic foraminiferal assemblages indicating temperate cold water, especially in Sample 1-2,72 cm. where Globorotalia pachyderma (predominantly sinistral) was recorded, associated with Globorotalia inflata and Globorotalia scitula. One sample taken in Core 1, Section 5 yielded a warm-temperate planktonic foraminiferal assemblage with: Globorotalia truncatulinoides (right and left coiling), Globorotalia cf. cavernula (one specimen), Hastigerinella digitata, $\mathrm{H}$. praedigitata, Globorotalia inflata, Globigerinoides ruber (white and pink colored), Globigerinoides tenellus, and Globorotalia anfracta. In Sample 1, CC, Hyalinea balthica was found.

\section{Pliocene}

Core 2, Section 1 belongs to the Pliocene and contains a highly condensed section with at least three zones, respectively: $2-1,24 \mathrm{~cm}$ : Globorotalia inflata Zone; 2-1, $68 \mathrm{~cm}$ : Globigerinoides obliquus extremus Zone; 2-1, $125 \mathrm{~cm}$ : Globorotalia margaritae evoluta Zone.

Some planktonic foraminifers were investigated in the cement of the volcanic breccias of Sample 3 - 3, $120 \mathrm{~cm}$. Orbulina and some Globigerinoides were found associated with thick-walled species which may belong to the genus Spheroidinellopsis. One sample taken at the top of Core 4 was barren.

Another sample taken in 13, CC, yielded a mixed microfauna from the Quaternary, upper Pliocene, and lower Pliocene. This is a downhole contamination. 


\section{Benthic Foraminifers}

The Pliocene-Pleistocene benthic foraminifers recovered from the two cores which contained them (Cores 1 and 2) are typical of the faunas generally known from the Tyrrhenian Basin of today. There appears to be a great deal of downhole contamination in several of the samples. Benthic foraminiferal tests are rare in the sediments and are generally well preserved. There is a noticeable change in the taxonomic make-up of the Site 373 fauna compared to that found in Sites 371 and 372 in sediments of comparable age. This may be due to: (a) an insufficient number of samples for the adequate representation of the fauna; (b) the increased presence of shelf elements which have reached the bathyal plain; (c) the greater depth of the sea floor at Site 373 compared to Sites 371 and 372; and/or (d) a different faunal assemblage in the Tyrrhenian Basin from that in the Balearic Plain.

When the displaced taxa are removed from the assemblages, the fauna suggests a mesobathyal habitat ( $>1000-1300 \mathrm{~m}$ ) for the Pliocene and Quaternary. The species which suggest this interpretation are: Quinqueloculina venusta, a mid-mesobathyal species, and the upper mesobathyal species Articulina tubulosa and Gyroidina lamarckiana.

\section{SEDIMENTATION RATES}

Coring in the sedimentary section at Site 373 is quite inadequate to calculate sedimentation rates precisely.

The oldest fossil assemblages recorded from the sediments above the volcanic sequence indicates ages within the MP1-3 and NN14 zones, that is approximately 3.5 m.y. The youngest absolute age recorded from the basalts is again 3.5 m.y. This age determination gives an average sedimentation rate for the PlioPleistocene sequence of $7.7 \mathrm{~cm} / 10^{3} \mathrm{yr}$.

This average rate obviously differs from the true values since in Core 2 a condensed sequence is present, as a drilling breccia overlying the volcanogenic series (Figure 6) and spanning all the nannofossil and foraminiferal zones of the upper Pliocene ( $0.5 \mathrm{~m} . \mathrm{y}$.).

Figure 7 shows the only possible sedimentation rate curve that can be extracted from the paleontological determinations as related to the sequence of zonal boundaries and magnetic reversals as in Ryan et al. (1974). This is based on: (1) a Plio-Pleistocene boundary interpolated between Cores 1 and 2 at about -187 meters; (2) the upper/lower Pliocene contact (3.3 m.y.) placed at 268.7 meters in Core 2, Section 1 (see Figure 6); (3) the 3.5-m.y. age given for the contact of the sedimentary and volcanic sequences.

These give rates of $5.4 \mathrm{~cm} / 10^{3} \mathrm{yr}$ for the late Pliocene and $10.8 \mathrm{~cm} / 10^{3} \mathrm{yr}$ for the Quaternary, an increase which may be due to an increased incidence of volcanic ash deposition in the basin, as was proven for the Quaternary at Site 132 on the Tyrrhenian Rise to the west.

It should be emphasized, however, that the Core 2 sequence is truly condensed suggesting either considerably lower rates than this or the presence of numerous hiatuses.

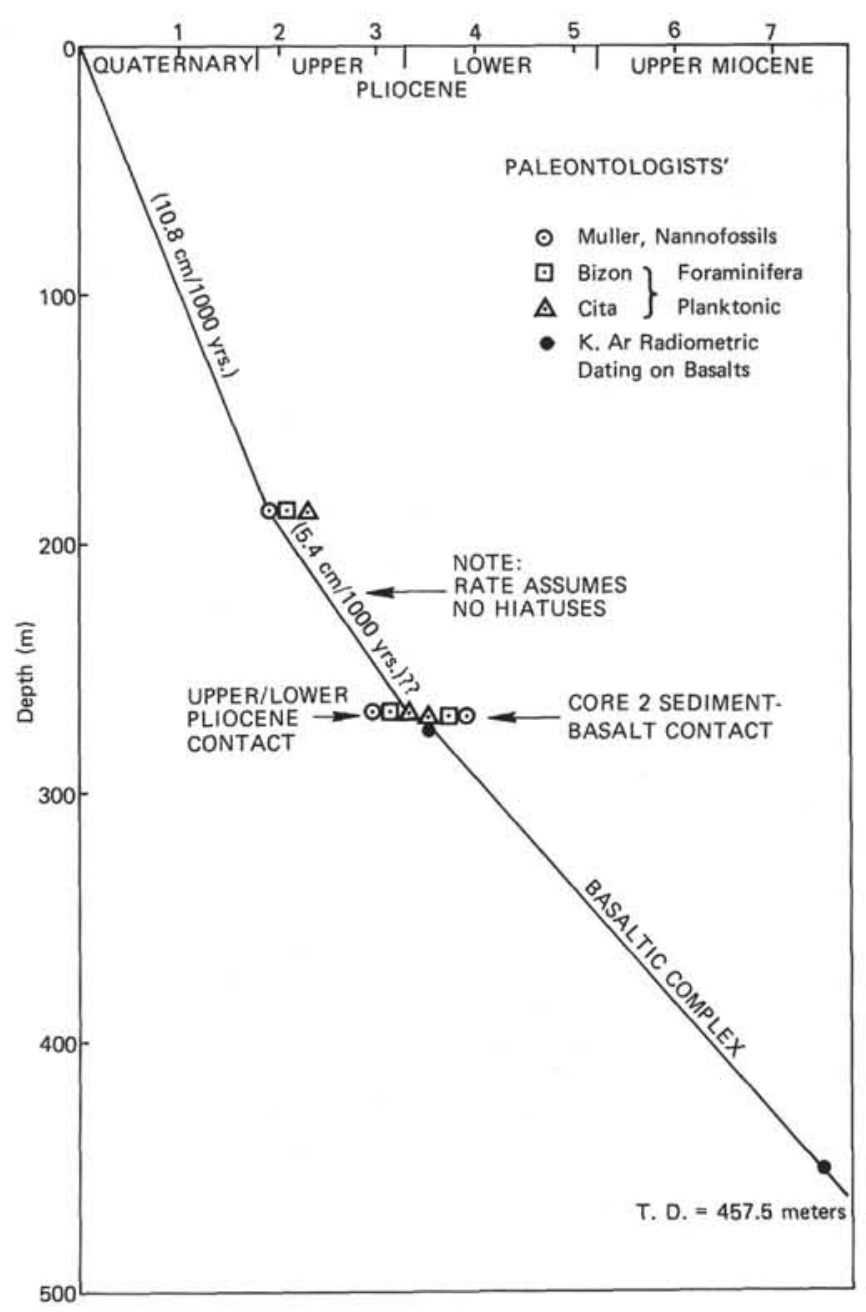

Figure 7. Sedimentation rates at Site 373.

\section{CORRELATION OF SEISMIC REFLECTION PROFILES WITH DRILLING RESULTS}

The correlation of seismic reflection and drilling results is based on the OGS profile MS1. The site is located on the flank of a seamount (here named "Seamount 42"). The profile (see Figure 8) shows clearly that horizontal Plio-Quaternary layers blanket an irregular basement topography and abut against the flanks of the seamount. Numerous reflections are present in the Plio-Quaternary cover, but none can be identified by this drilling. The irregular surface of the volcanic basement and the steepness of the flank of the seamount cause many diffractions which led to considerable uncertainty before drilling as to the depth of acoustic basement. It was very difficult to estimate a thickness for the Plio-Quaternary overburden precisely. Drilling led to a correlation of the top of a highly diffracting horizon with the top of the volcanic breccias encountered in Core 2 at 270 meters subbottom.

\section{SUMMARY AND CONCLUSIONS}

The site was located in the central Tyrrhenian Abyssal Plain at $39^{\circ} 43.68 \mathrm{~N}, 12^{\circ} 59.56 \mathrm{E}$. The hole penetrated 457.5 meters to 187.5 meters below the 


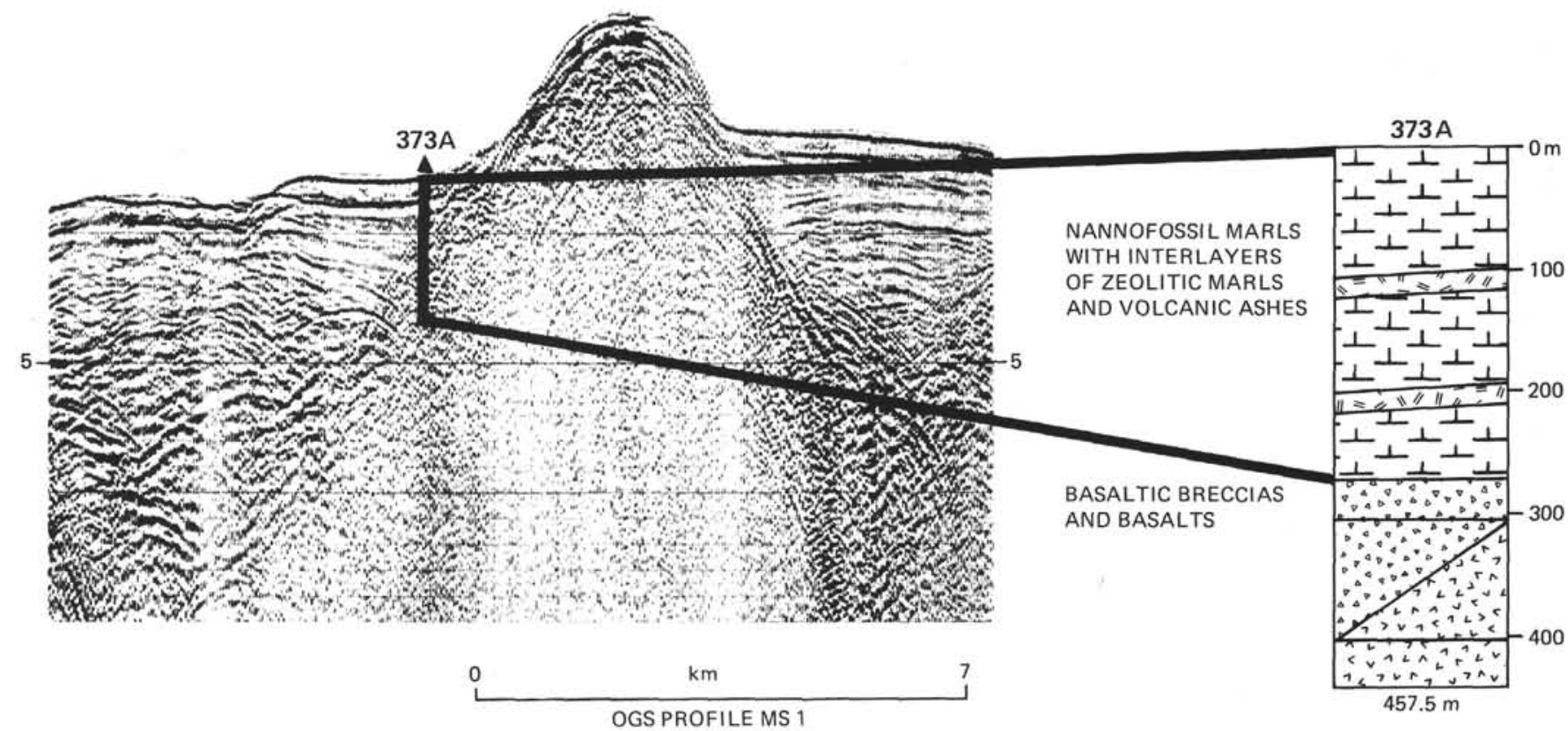

Figure 8. Correlation of OGS Seismic Reflection profile MSI with drilling results at Site 373.

acoustic basement. It was abandoned when the bottom-hole assembly became plugged by sand and basalt cuttings.

Although the hole penetrated 270 meters of PlioQuaternary sediments at this site, only one core was obtained from the Quaternary. This core contained nannofossil marls and interbedded tephras together with the remains of one sapropel layer. These sediments were deposited at a very high accumulation rate, about $10.8 \mathrm{~cm} / 10^{3} \mathrm{yr}$, as is commonly the case for the Mediterranean abyssal plains. The Pliocene is represented by Section 1 of Core 2 and consists of nannofossil marls and tephras and includes an indurated and a laminated zeolite-bearing, calcarenitic horizon. Four of the six Pliocene foraminiferal zones were recognized here in a 1-meter interval. This is indicative of a slow sedimentation rate and/or the presence of hiatuses. As has been the case at many other Mediterranean drill sites, the earliest Pliocene sediments are missing on this topographic high.

A thin ferruginous dolomite layer is present immediately above the acoustic basement of basaltic breccias and flow basalts. This Tyrrhenian dolomite is probably a dolomitized pelagic sediment, since it contains molds of foraminifers. It probably owes its origin to sea-floor diagenesis, as it has an isotopic composition similar to pelagic sediments formed under submarine conditions during the Quaternary in the Mediterranean (Fontes and Desforges, 1957). Similar dolomite was found between seamount basalt and the overlying sediment in the Mohole at its Guadalupe site off the Californian Coast (Degens and Epstein, 1964).

Site 373 penetrated 187.5 meters into the acoustic basement. The basement sequence consists of basalt breccias and basalt flows. The breccia fragments range from sand to small boulder size. Those with rims and palagonitized glass are obviously broken pillow fragments. The basalt breccias of Cores 3 and 4 are probably "pillow breccias" in part. Others may have been formed by slumping on steep slopes or by tectonic brecciation (Bernoulli et al., this volume). The breccia fragments are cemented in a carbonate matrix that is in part sparry calcite and in part fine-grained gray and brown limestone. Some of these latter limestones contain planktonic foraminifers of Pliocene age, and they are obviously indurated pelagic oozes. Some of the flow basalts are porphyritic and are vesicular or amygdaloidal. Others, especially those from the lowest cores, are fine grained. They have all suffered some degree of alteration.

We recognize that recovery was poor, and that the recovered cores represent only about $10 \%$ of the drilled section. Also there are interbeds of soft materials which may represent basalt breccias or rubble rather than nannofossil oozes, because we found no downhole contamination of sediments older than Pliocene in any of the cores. A bucketful of debris recovered from the drill collar consisted almost entirely of basalt cuttings with a minor amount of Quaternary sand. The Tyrrhenian basement sequence nevertheless appears similar to that recovered by Leg 37 drilling in the Mid-Atlantic Ridge region (cf. DSDP Holes 332A and B and 333).

The age of the basalt ranges from latest Miocene to early Pliocene. The oldest dated fossiliferous sediment above the basalt is early Pliocene (MPl-3), or 3.3 to 4.2 m.y. The limestone matrix yields microfossils which are probably early Pliocene in age. The basalt from Core 4 has been dated as $3.5 \pm 0.5$ m.y., or early 
Pliocene, by Barberi et al. (this volume). The age of Core 7 is most probably also early Pliocene, or 3.5 to 5.6 m.y. (Barberi et al., this volume; Kreuzer et al., this volume), although a somewhat higher age of 7.2 m.y. was obtained (Savelli and Lippanni, this volume). The lowest basalt samples (Core 12) were dated as late Miocene, or 6.25 to 7.5 m.y. (Barberi et al., this volume).

The chemistry of the basalt is very similar to typical oceanic tholeiites (Barberi et al., this volume; Kreuzer et al., this volume) although some affinity to high $\mathrm{Al}$ basalt was noted (Dietrich et al., this volume). Oceanic tholeiites of similar chemistry are known both from seamounts on spreading ridges and from back-arc basins. Their presence in the Tyrrhenian is consistent with postulations which have compared this Mediterranean basin to Pacific back-arc basins (Barberi et al., this volume).

\section{Heat Flow}

Two downhole temperature measurements were made in the sediment above the basalt flank of the seamount at 106 and 125 meters subbottom in Hole $373 \mathrm{~A}$. These data, in conjunction with a limited number of thermal conductivity measurements, were used to calculate a heat flow of $1.72 \mathrm{cal} / \mathrm{cm}^{2} \mathrm{sec}$. This value is above the global heat-flow average of $1.35 \mathrm{cal} / \mathrm{cm}^{2}$ sec (Langseth, 1969), but is somewhat lower than the mean $\left(2.83 \pm 1.07 \mathrm{cal} / \mathrm{cm}^{2} \mathrm{sec}\right)$ of 12 nearly Tyrrhenian Sea heat-flow values which range from 0.72 to $4.14 \mathrm{cal} / \mathrm{cm}^{2} \mathrm{sec}$ (Erickson, 1970). It is likely that the close proximity of basaltic rocks having much higher thermal conductivities than the sediment in which the temperatures were measured is responsible for the conduction of heat away from sediment-covered areas, thus causing a local reduction in the heat flow measured on the flanks of the seamount. The substantiation of generally high heat flow in the Tyrrhenian Sea basin postulates an origin as a back-arc basin (Barberi et al., this volume) and suggests that the seamount on whose flank the measurement was made is no longer an active volcanic feature. For additional details see Erickson and von Herzen (this volume).

\section{REFERENCES}

Biju-Duval, B., Letouzey, J., Montadert, L., Courrier, P., Mugniot, J. F., and Sancho, J., 1974. Geology of the
Mediterranean Sea basins, In The geology of continental margins. Burk, C., and Drake, C. H. (Eds.) New York (Springer Verlag).

Carlisle, D., 1963, Pillow breccias and their aquagene tuffs, Quadra Island, British Columbia: J. Geol., v. 71, p. 48-71.

Cita M.B., Chierci, M.A., Ciampo, G., Moncharmont, Z. M., O'Onofrio, S., Ryan, W.B.F., and Scorziello, R. 1973. The Quaternary record in the Tyrrhenian and Ionian basins of the Mediterranean. In Ryan, W.B.F., Hsü K.J. et al., Initial Reports of the Deep Sea Drilling Project, Volume 13: Washington (U.S. government Printing Office), p. 1263-1339.

Degens, E.T. and Epstein, S., 1964. Oxygen and carbon isotope ratios in co-existing calcites and dolomites from recent and ancient sediments: Geochim. Cosmochim. Acta, v. 28 , p. 23-44.

Erickson, A.J., 1970. The measurement and interpretation of heat flow in the Mediterranean and Black seas: Ph.D. thesis, M.I.T., Cambridge, Massachussetts.

Fontes, J.C., and Desforges, G., 1965. Oxygen 18, Carbon 13 and radiocarbon as indicators of Wurmian cold and deep genesis in Western Mediterranean carbonate sediments: IX Congr. Inst. Sedim., Proc. Nice, 1975. v. 8, p. 29-38.

Garrison, R.E., 1972. Inter- and intrapillow limestones of the Olympic Peninsula, Washington: J. Geo., v. 80 , p. $310-$ 322.

1973. Space-time relations of pelagic limestones and volcanic rocks, Olympic Peninsula, Washington: Geol. Soc. Am. Bull., v. 84, p. 583-594.

Glangeaud, L., 1962. Paleogeographie Dynamique de la Mediterranée et ses Bordures. Le rôle des phases PontoPlio-Quaternaires: In Océanographie Géologique et Geophysique de la Mediterranée Occidentale, Colloques Internationeaux C.N.R.S. Ville Franche, p. 125.

Kendall, A.C., and Tucker, M.E., 1973. Radiaxial fibrous calcite: A replacement after acicular carbonate: Sedimentology, v. 20 , p. $365-389$.

Langseth, M.C., 1969, The flow of heat from the earth and its global distribution at the surface: Paper presented at AIAA fourth Thermophysics Conference, San Francisco, June 16-18, 1969.

Ryan W.B.F., Cita M.B., Dreyfus Ranson, M., Burkle, L.H., and Saito T., 1974. A paleomagnetic assignment of Neogene stage boundaries and the development of isochronous datum planes between the Mediterranean, the Pacific and Indian Oceans in order to investigate the response of the World Ocean to the Mediterranean "Salinity Crisis": Riv. Ital. Pal. Strat., v. 80, p. 631-688.

Von Rad, U., 1974. Great Meteor and Josephine Seamounts (eastern North Atlantic): Composition and origin of bioclastic sands, carbonate and pyroclastic rocks: "Meteor"'Forsch.-Ergeb., Reihe C, No. 19, p. 1-61. 


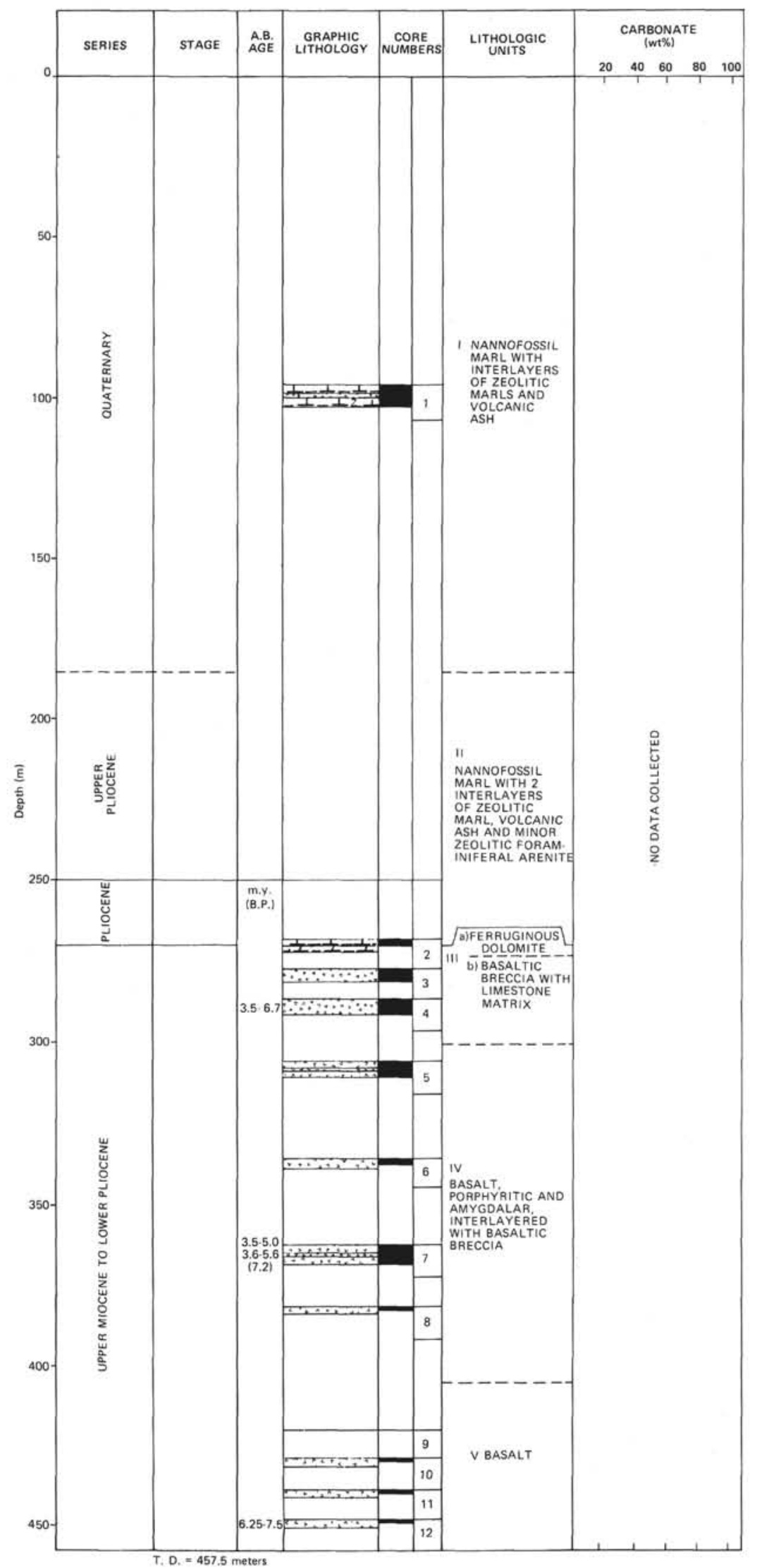


SITE 373: TYRRHENIAN BASIN

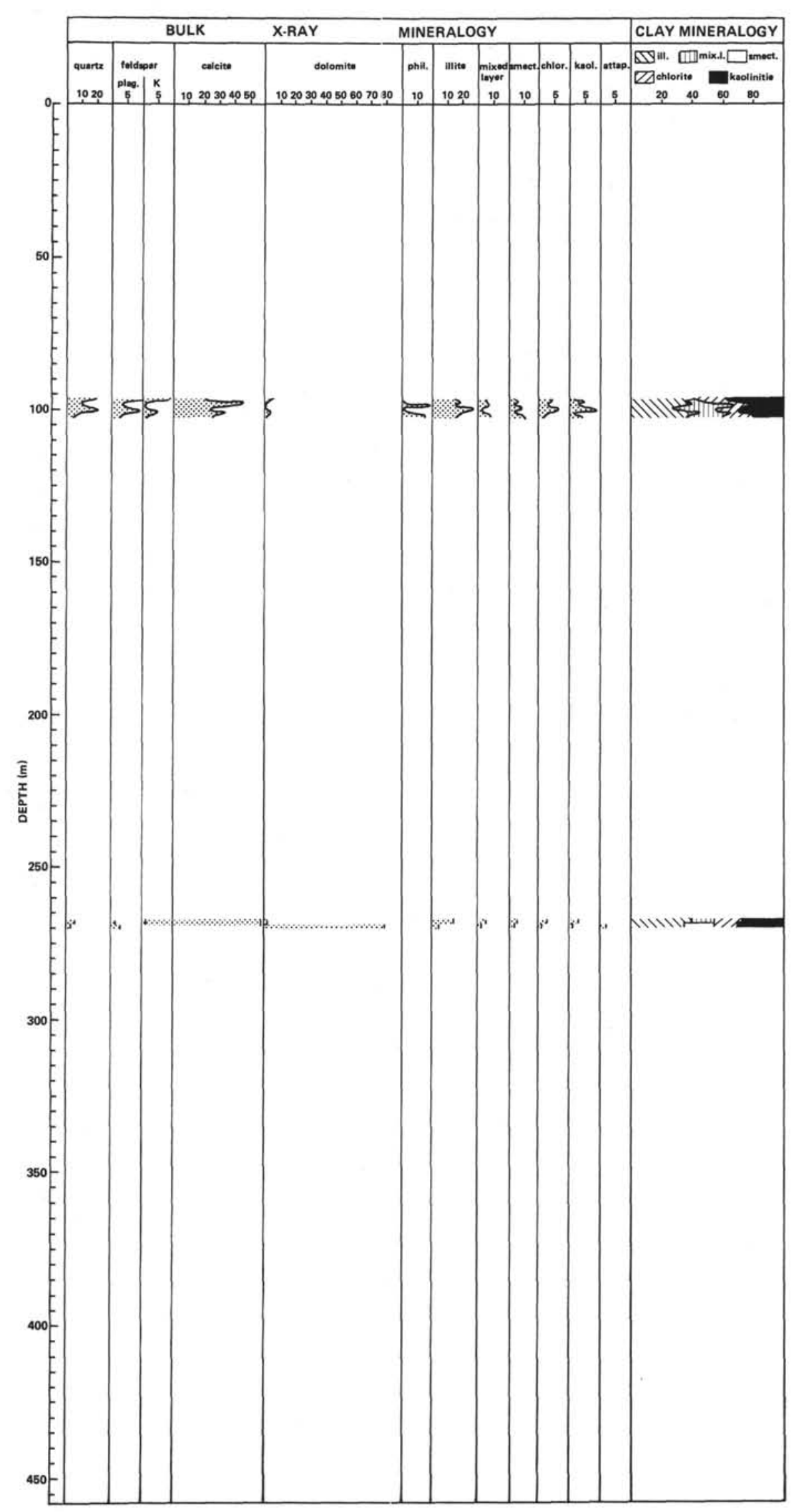

165 


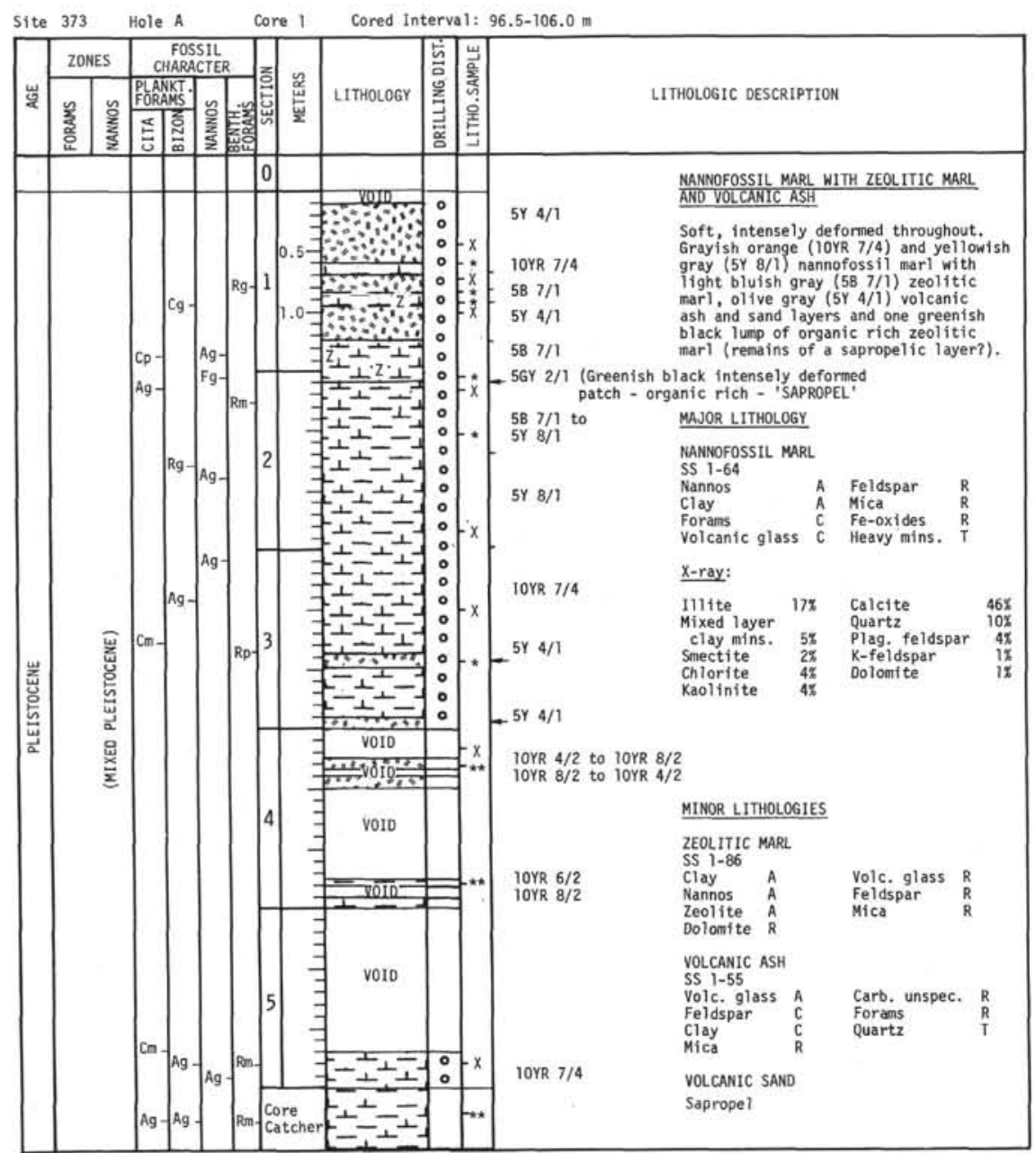

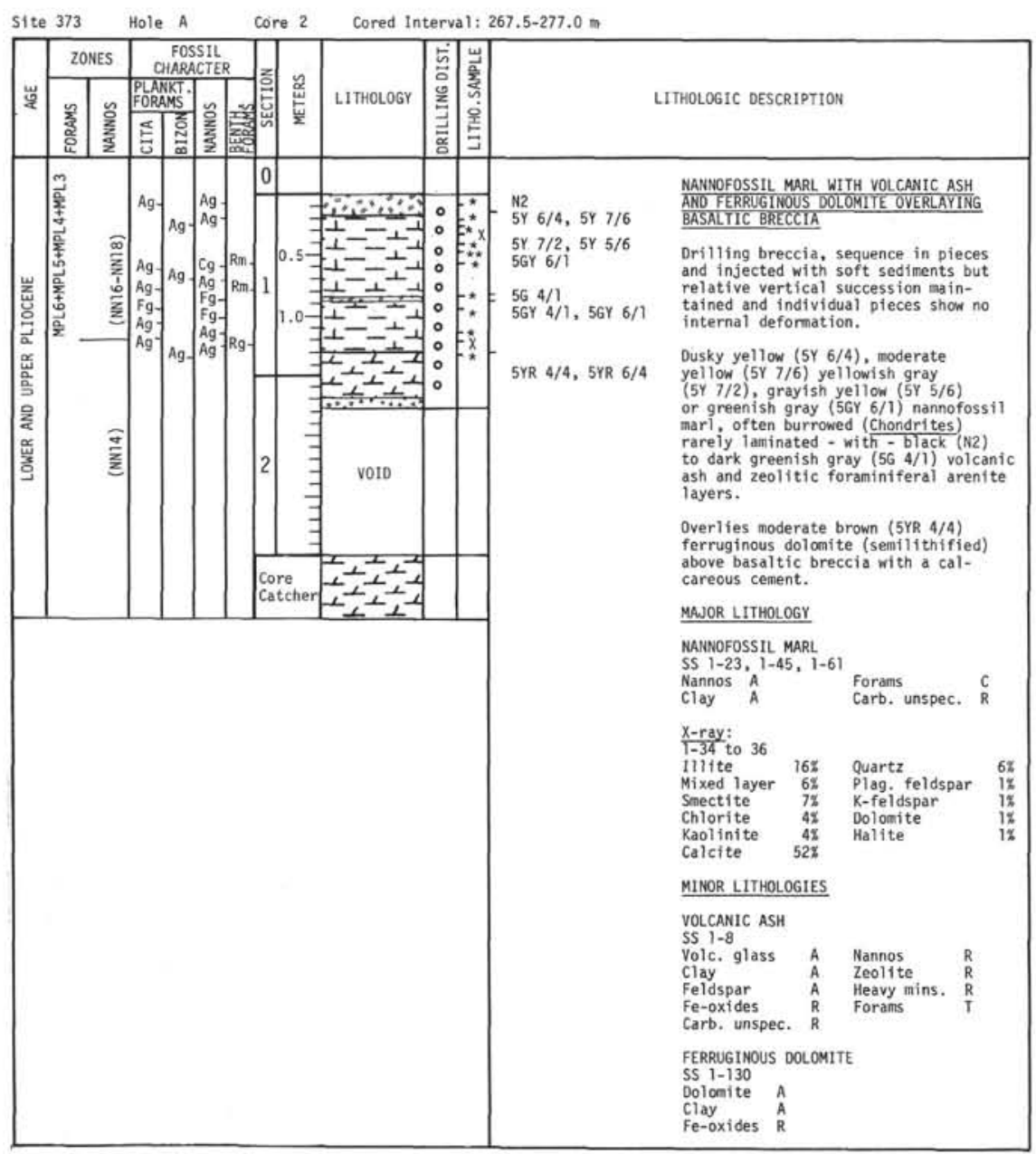



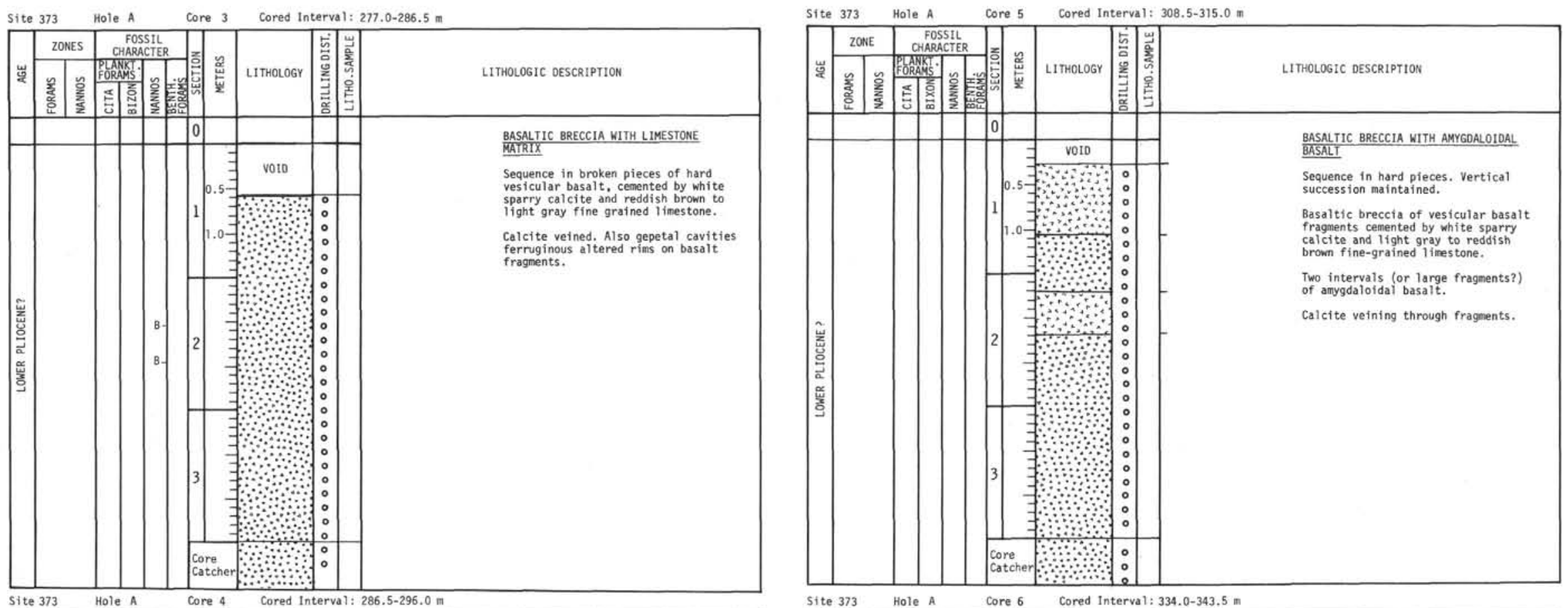

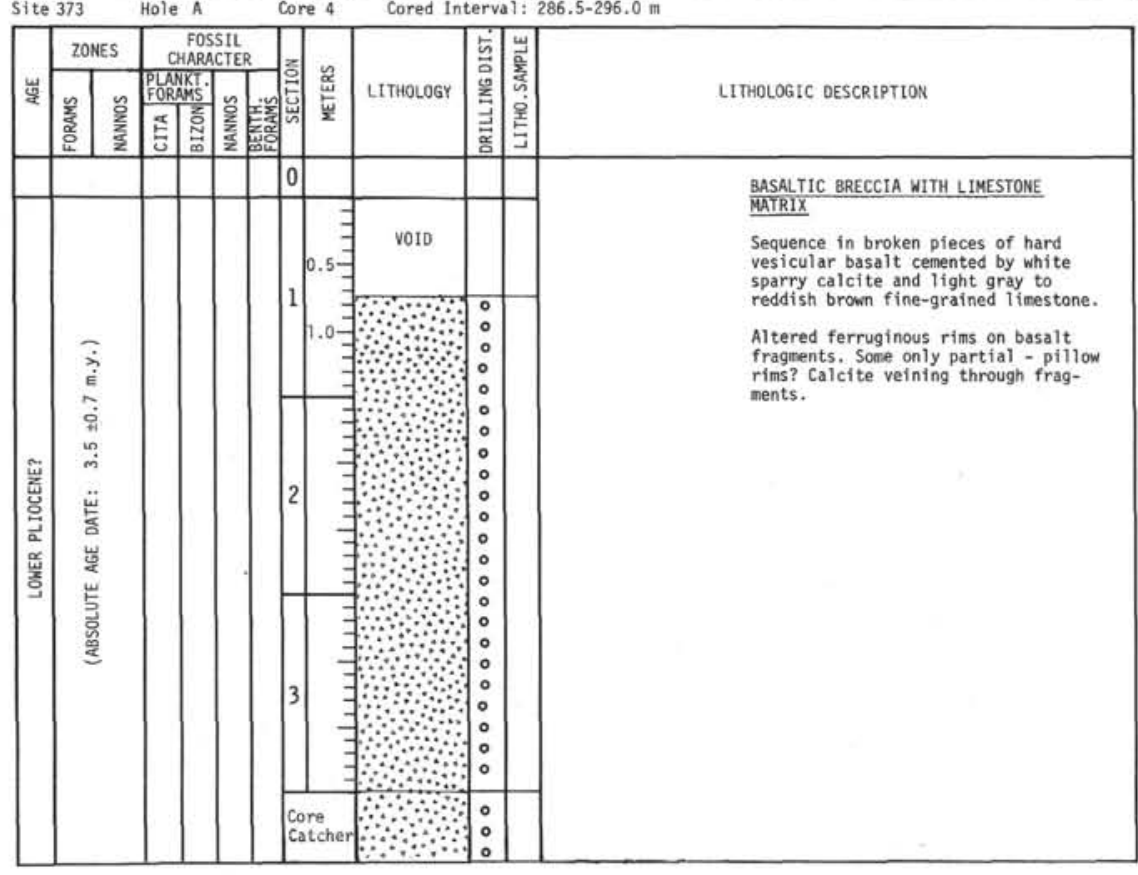

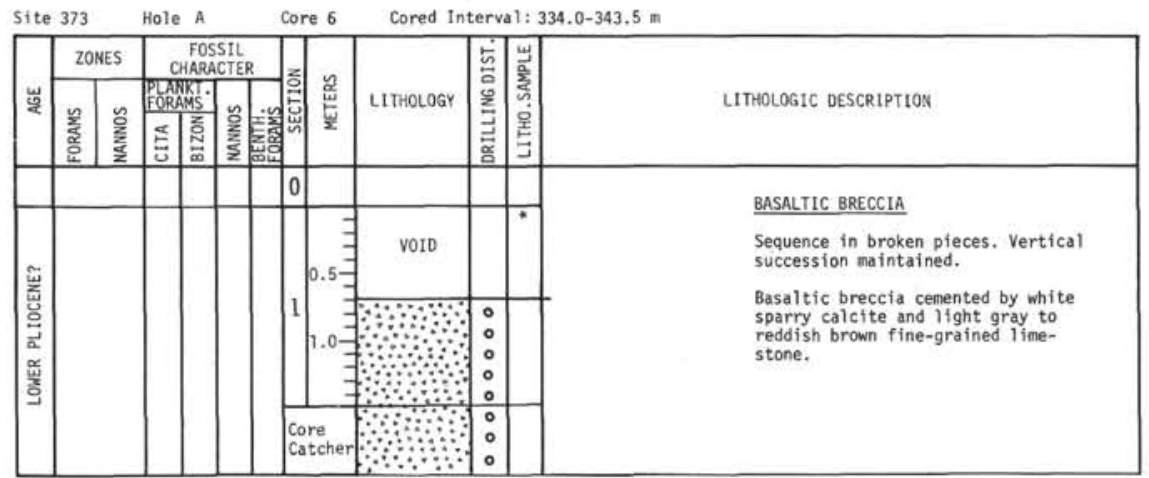




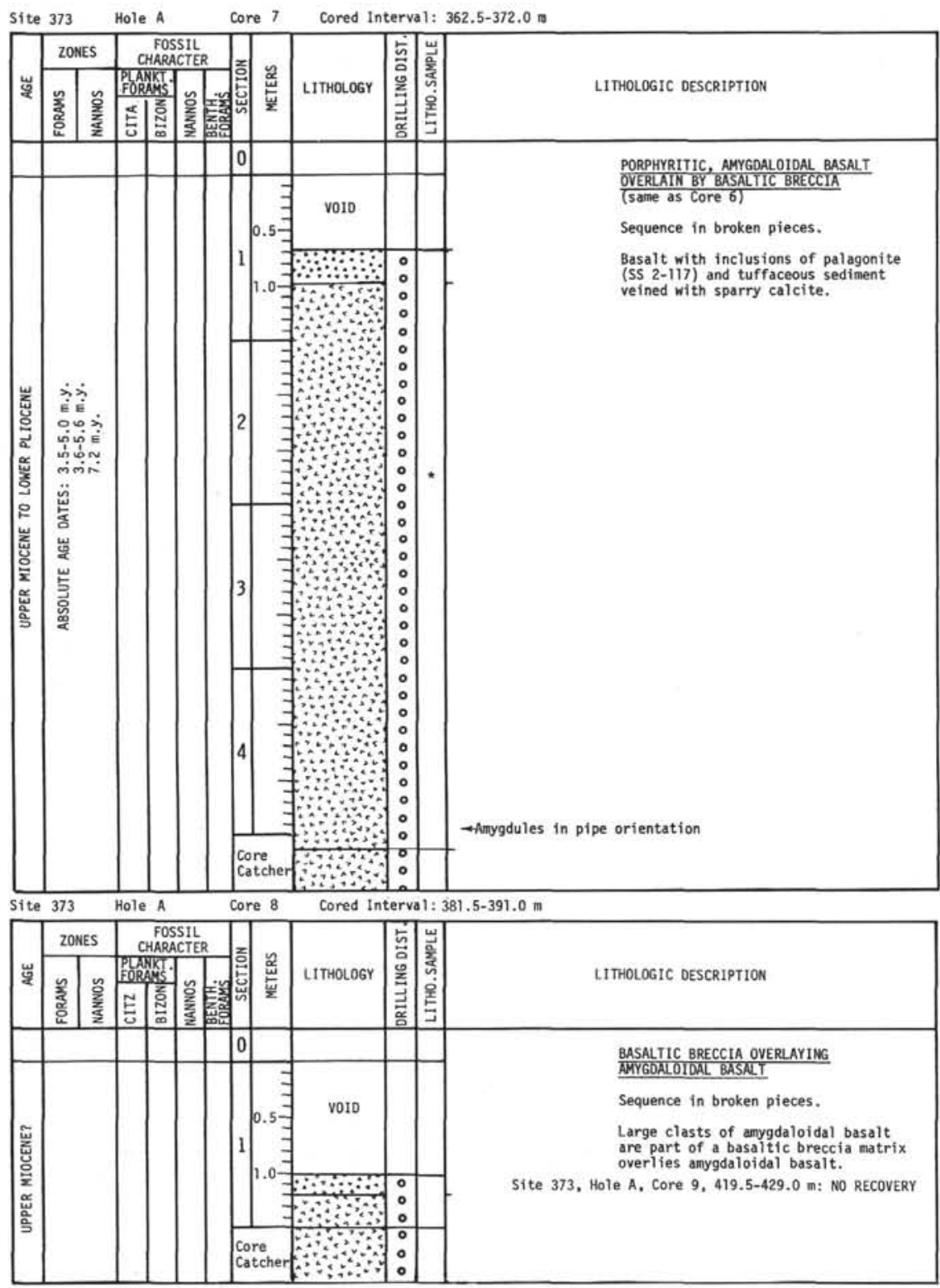
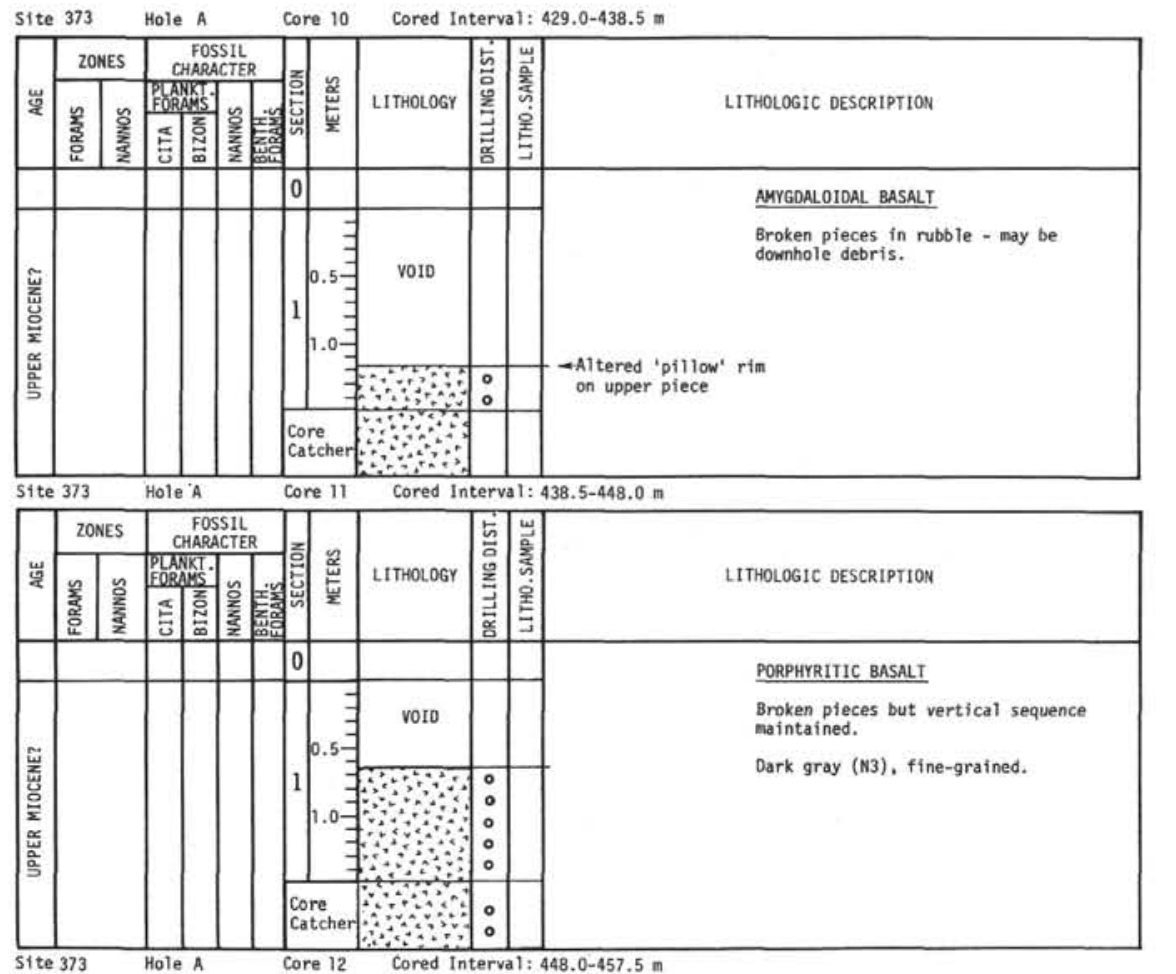

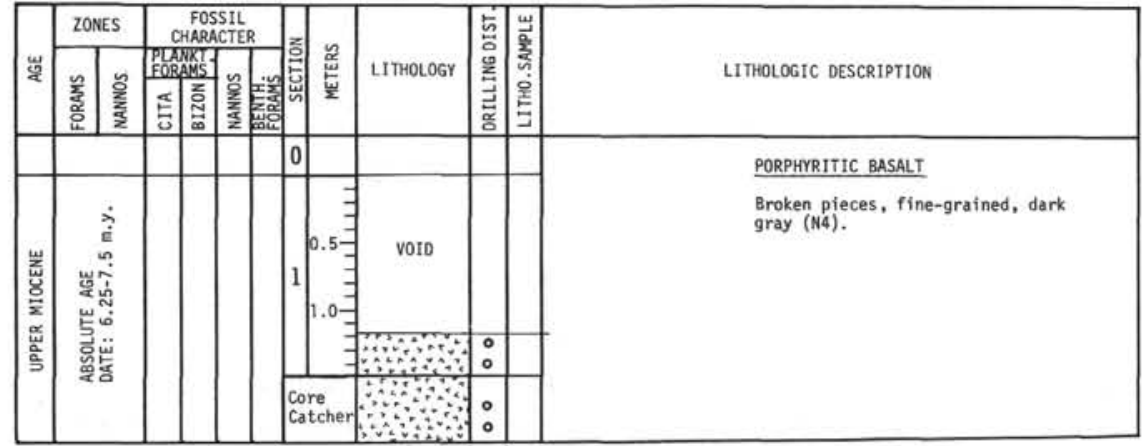




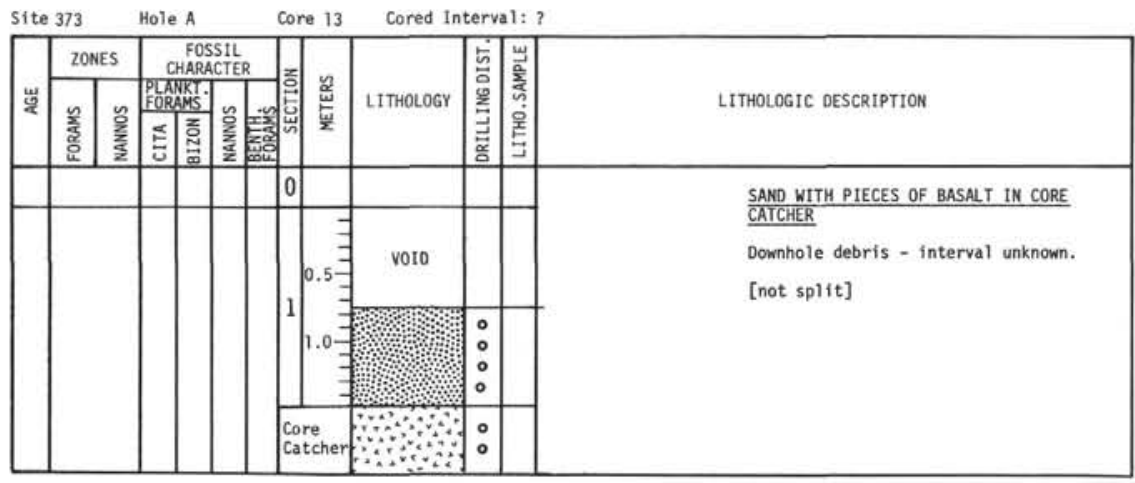

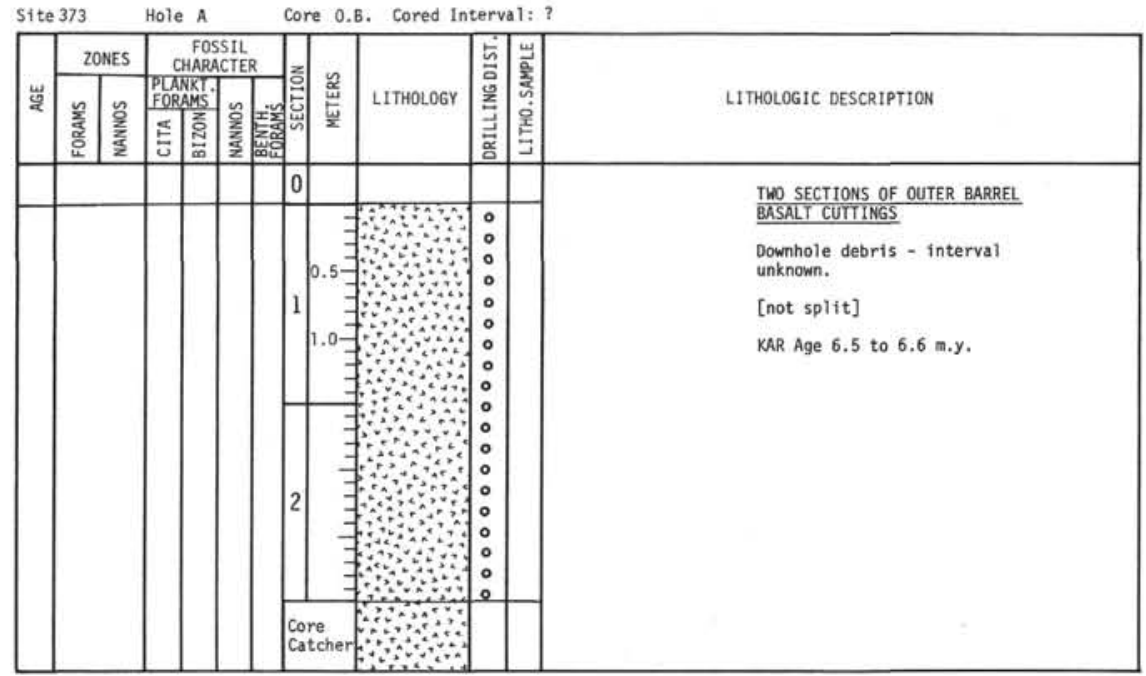




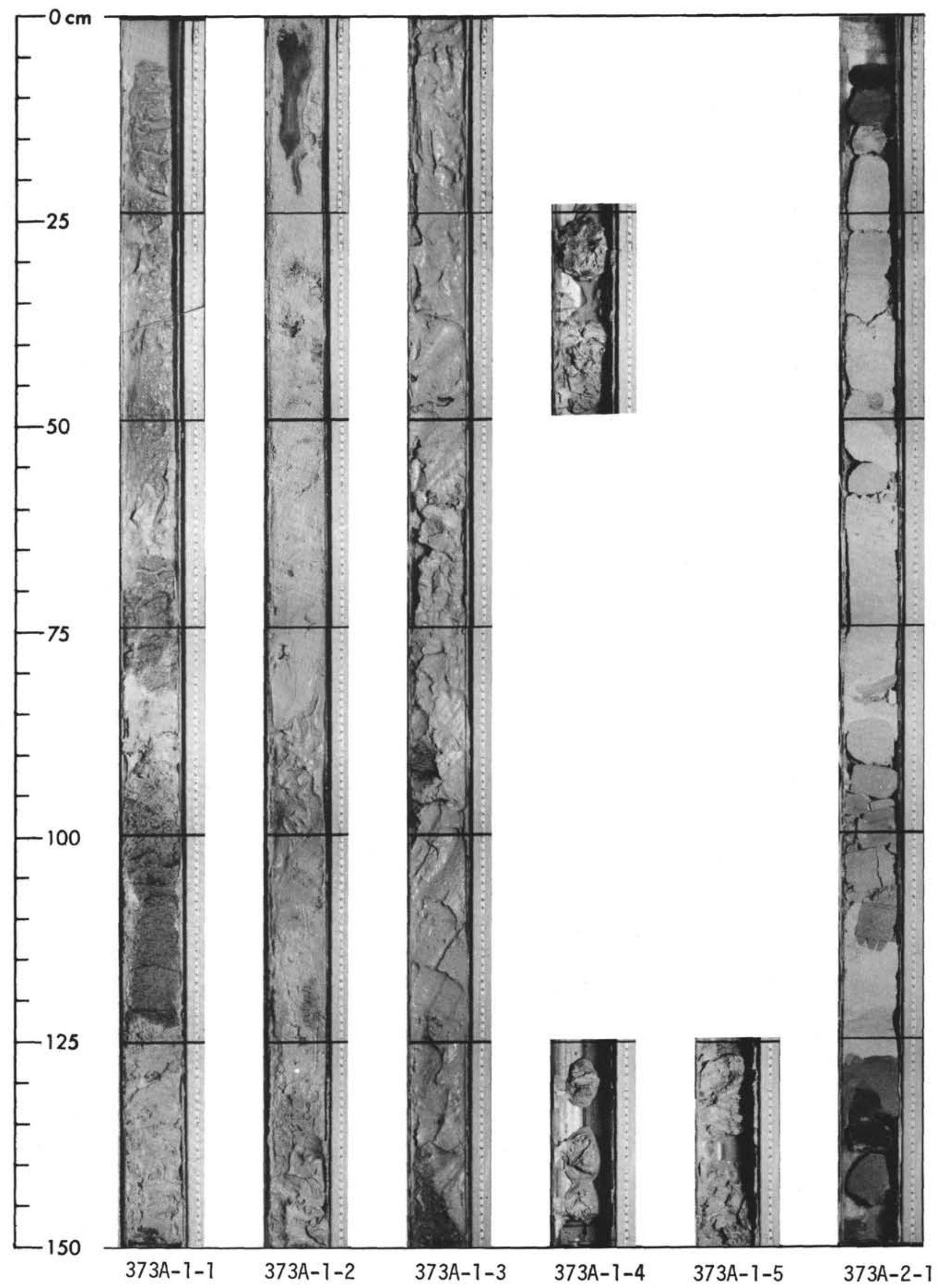


SITE 373: TYRRHENIAN BASIN

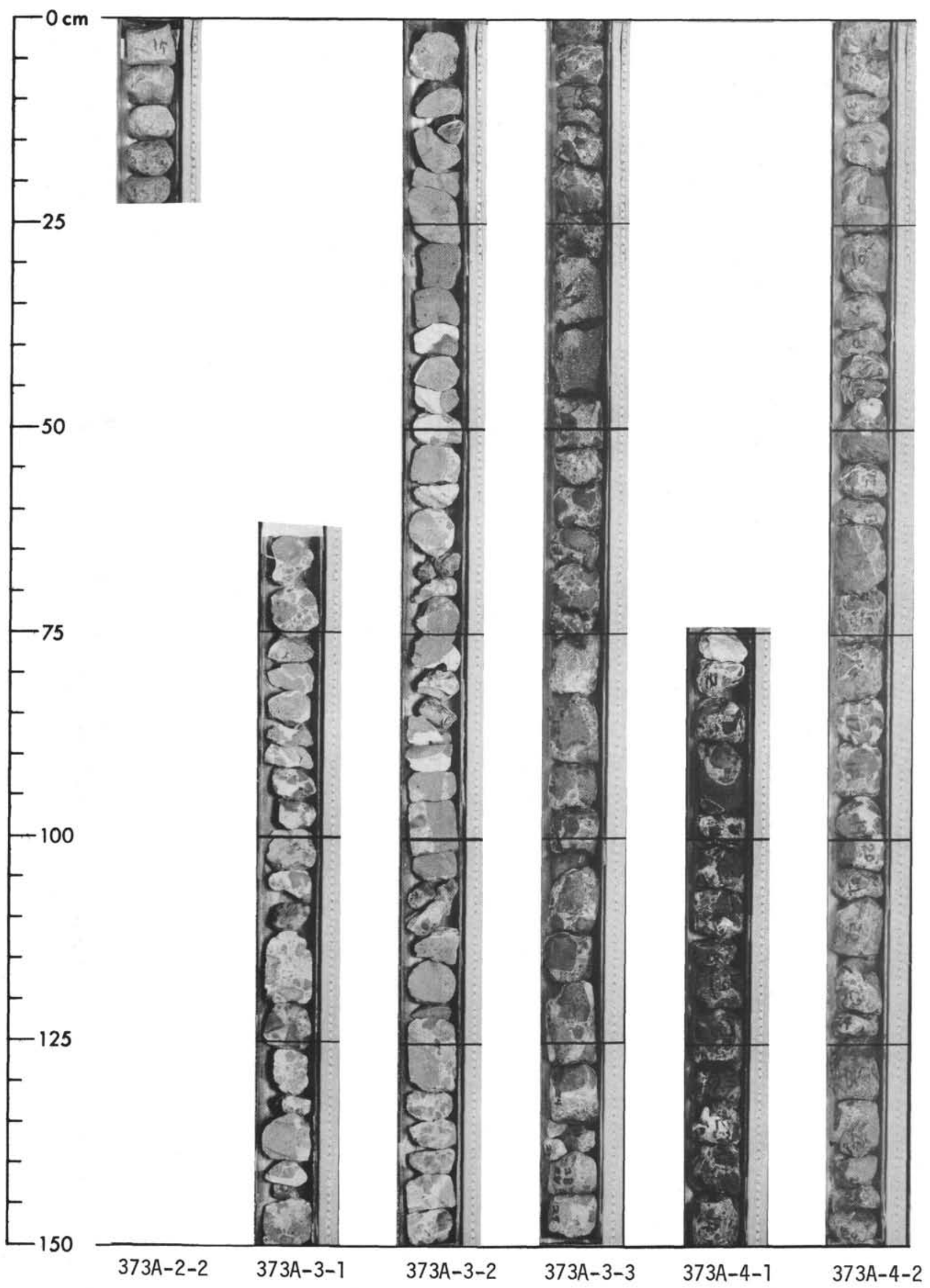




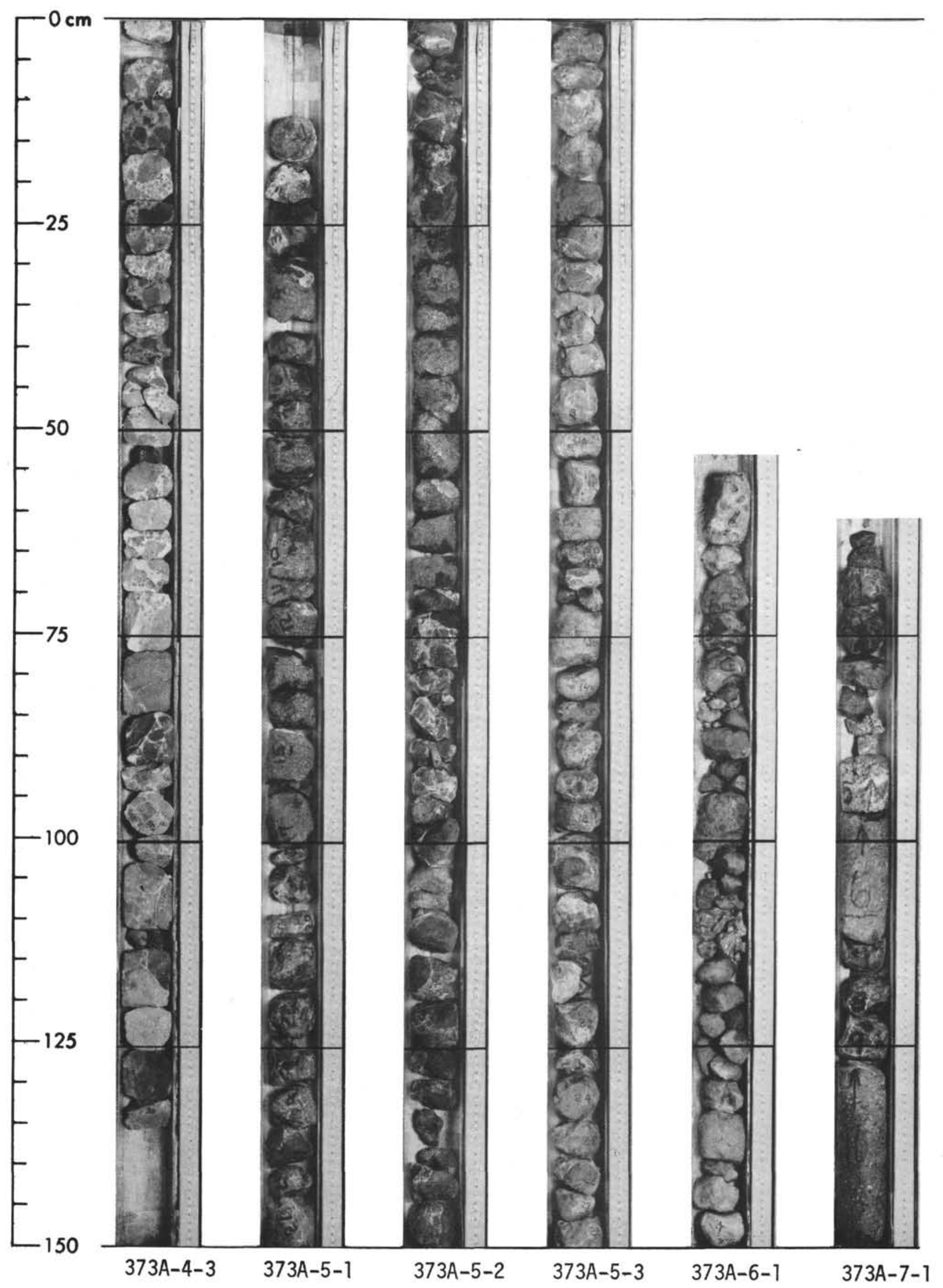




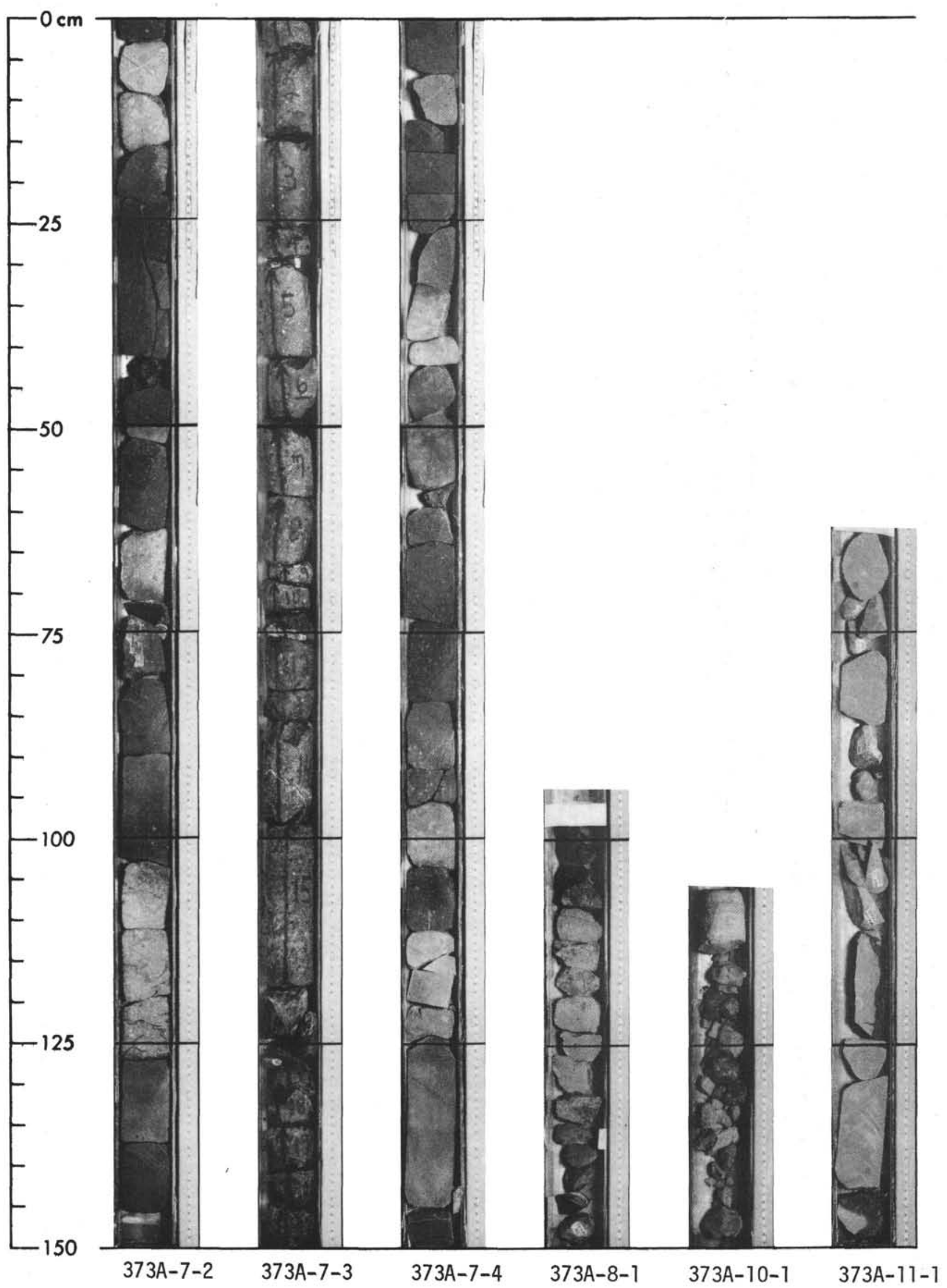


SITE 373: TYRRHENIAN BASIN

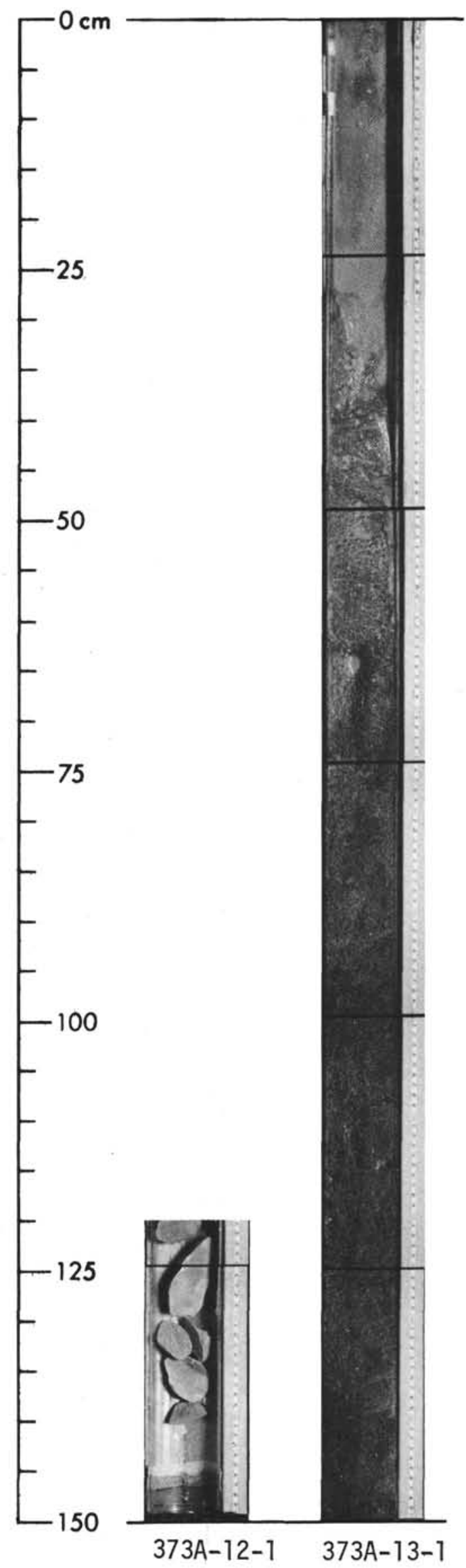

